\title{
ECONOMIC GROWTH IN MESOAMERICA: OBSIDIAN CONSUMPTION IN THE COASTAL LOWLANDS
}

Barbara L. Stark ${ }^{a}$, Matthew A. Boxt ${ }^{b}$, Janine Gasco ${ }^{c}$, Rebecca B. González Lauck ${ }^{d}$, Jessica D. Hedgepeth Balkin $^{\mathrm{e}}$, Arthur A. Joyce ${ }^{\mathrm{e}}$, Stacie M. King ${ }^{\mathrm{f}}$, Charles L. F. Knight ${ }^{\mathrm{g}}$, Robert Kruger ${ }^{\mathrm{h}}$, Marc N. Levine ${ }^{\mathrm{i}}$, Richard G. Lesure $^{\mathrm{j}}$, Rebecca Mendelsohn ${ }^{k}$, Marx Navarro-Castillo', Hector Neff ${ }^{\mathrm{m}}$, Michael Ohnersorgen ${ }^{\mathrm{n}}$, Christopher Pool $^{\circ}$, L. Mark Raab ${ }^{p}$, Robert M. Rosenswig ${ }^{k}$, Marcie Venter ${ }^{q}$, Barbara Voorhies ${ }^{r}$, David T. Williams ${ }^{s}$, Andrew Workinger ${ }^{t}$

${ }^{a}$ School of Human Evolution and Social Change, Arizona State University, Tempe, AZ, 85287-2402, USA. Corresponding author, blstark@asu.edu

${ }^{b}$ Department of Anthropology, The California State University, Northridge, 18111 Nordhoff Street, Northridge, CA 91330 USA

${ }^{\mathrm{C}}$ Department of Anthropology, California State University Dominguez Hills, 1000 E Victoria, Carson, CA 90747 USA

d Sección de Investigación, Centro INAH Tabasco, Plutarco Elías Calles 401, Col. Jesús García 86040 Villahermosa, Tabasco, México

${ }^{\mathrm{e}}$ Department of Anthropology, University of Colorado at Boulder, Hale Science 350, 233 UCB, Boulder, CO 80309-0233 USA

${ }^{\mathrm{f}}$ Department of Anthropology, Indiana University, Student Building 130, 701 E. Kirkwood Ave., Bloomington, IN 47405, USA

${ }^{\mathrm{g}}$ University of Vermont Consulting Archaeology Program, 111 Delehanty Hall, 180 Colchester Avenue, Burlington, VT 05405, USA

${ }^{\mathrm{h}}$ Facultad de Antropología, Universidad Veracruzana, Xalapa, Veracruz, México

'Sam Noble Oklahoma Museum of Natural History and Department of Anthropology, 2401 Chautauqua Avenue, University of Oklahoma, Norman, OK 73072 USA

${ }^{k}$ University at Albany, Department of Anthropology, AS 237, 1400 Washington Ave., Albany NY 12222 USA

'CONACyT, Av. Insurgentes Sur 1582, Col. Crédito Constructor, Del. Benito Juárez C.P. 03940, México, D. F. Mexico

${ }^{m}$ Department of Anthropology, California State University Long Beach 1250 Bellflower Blvd., Long Beach, CA 90840, USA

${ }^{\mathrm{n}}$ Missouri State Parks, PO Box 176, Jefferson City, MO 65102-0176 USA

${ }^{\circ}$ Department of Anthropology, University of Kentucky, Lexington, KY 40506-0024 USA 
${ }^{\mathrm{p}}$ Department of Geosciences, University of Missouri-Kansas City, 5100 Rockhill Road, Kansas City, Missouri, 64110 USA

${ }^{9}$ Pennsylvania State University, Department of Anthropology, 409 Carpenter Building, State College, PA 16802 USA

${ }^{r}$ Department of Anthropology, University of California, Santa Barbara, Santa Barbara, CA 93106 USA

s South Dakota State Historical Society Archaeological Research Center, 217 Kansas City St., Rapid City, SD 57701 USA

${ }^{\mathrm{t}}$ Department of Sociology, Anthropology, and Geography, University of Tennessee, Chattanooga, 615 McCallie Avenue, Chattanooga, TN 37403 USA 


\section{Abstract}

Economic growth is rarely examined for ancient states and empires despite its prominence as a topic in modern economies. The concept is debated, and many measures of growth are inaccessible for most of the ancient world, such as gross domestic product (GDP). Scholars generally have been pessimistic about ancient economic growth, but expectations derived from dramatic growth in modern economies can lead to overlooking important evidence about economic change in the past. The measure of economic growth that we adopt focuses on the economic well-being of ordinary households. We evaluate one domain of evidence: imported obsidian implement consumption in the coastal lowlands of Mesoamerica. We situate the obsidian study against a backdrop of ideas concerning economic growth in ancient societies because such topics have received only modest attention for Mesoamerica. For the major Mesoamerican ceramic periods, we (1) display the already-known early technological shift in predominant techniques of obsidian implement production---from percussion and bipolar flakes to prismatic pressure blades---that led to more efficient tool production for long-distance trade, (2) note other lithic technological improvements, and (3) evaluate increased obsidian access with a growing market system in the last centuries of the prehispanic record.

Keywords economic growth; ancient economy; market development; Mesoamerica; lithic technology; obsidian

We contribute to the study of economic growth in ancient civilizations by evaluating one category of evidence in Mesoamerica, the household consumption of obsidian implements in the coastal lowlands. After introducing the study and the concept of economic growth, we briefly review proposals about Mesoamerican economic growth and how archaeologists can examine it, including our approach involving household consumption in the general population. We then mention contrastive ideas concerning obsidian in Mesoamerica, followed by an introduction to our sample of assemblages, the variables used, and our expectations. We close with results and conclusions.

Obsidian is volcanic glass found in varied locations in the Mexican and Guatemalan highlands. In the coastal lowlands, obsidian is not present geologically, and other cryptocrystalline raw materials also are largely absent, such as chert. Both the Gulf and Pacific coastal lowlands primarily relied on longdistance trade for obsidian. Further, these regions were moderately distant consumers and not the locations of powerful centers that at times controlled one or more highland obsidian sources. The 
coastal lowlands are defined here as the Gulf and Pacific lowlands below $500 \mathrm{~m}$ elevation (tierra caliente is below $1000 \mathrm{~m}$ ); the settlements providing information are within 300 masl (Figure 1), the highest being in the Tuxtla Mountains, which are low volcanics interrupting the Gulf coast. We exclude the Yucatan peninsula, which has a limestone substrate with chert deposits.

The empirical data were assembled and studied in a joint endeavor (Table 1). Many fields of modern research, such as genetics, accumulate large shared databases. Despite voluminous archaeological data, often they are used primarily at the site or regional level. Our cooperation to compile and analyze data, mostly unpublished, is an attempt to realize some of the archaeological potential of cooperative datasets. Certain research questions cannot be addressed piecemeal using individual sites or even regions, but instead require a larger-scale effort. Published sources may not provide the requisite basic data because archaeology does not enjoy agreement about standards for reporting. The data we employ are so basic that we hope they will be among those eventually enshrined as part of a baseline in dissemination.

We consider ancient economic growth to be economic change benefitting populations in general over a long time span through increasing per capita productivity. Two major rationales underscore the importance of considering economic growth in Mesoamerica or other areas of ancient civilization. Economic changes involving growth are a basis for comparisons among ancient societies to detect and understand common and exceptional situations, and economic growth may represent longlived change in the archaeological record---for example, the "Neolithic Revolution," the shift to foodproducing economies, as described by Childe (1951).

We accompany our obsidian consumption study with a brief review of issues concerning economic growth for archaeology. Despite the rationales for considering economic growth in the ancient world, the prominence of agrarian pursuits and the frequent rise and demise of states that disrupted economic conditions make the topic an infrequent focus. Upper social strata often inhibited growth by fostering accumulations of land and labor as the basis for power, rather than investments in commerce or technology. In contrast, sustained increases in productivity are a main economic theoretical focus and empirical situation of modern times.

Not all modern economic models project continuing growth. Maintenance of growth poses theoretical problems (Hahn and Matthews 1964; Kaldor and Mirrlees 1961-1962; Sen 1970; Solow 1956; Swan 1956; Todaro 1997:88-91), especially if non-renewable natural resources are considered 
(Erreygers 2009; Malthus 1997 [1798]; Snowdon 2009). Technological change is an important contributor to recent economic growth (Sandilands 2009), accounting for up to $87.5 \%$ in one analysis (Solow 1957:418) and, possibly, combined with other factors, approximately half in another analysis (Blanchard and Fisher 1989:4). Important externalities include not only technological innovations but also social capital development (such as education) (Snowdon 2009:247) and urbanization, which improves communication and innovation as well as concentrating demand (Bettencourt 2013; Kremer 1993; Lee 1988). Many recent innovations involve non-rival goods that are argued to both respond to and accommodate population growth and productivity increases, or create new demand (Jones and Romer 2010). Social capital and technological innovation figure in arguments that economic growth can accelerate or even become indefinite without Malthusian checks. Fluctuations in growth, lags, and declines ("business cycles") are another challenge for models (Blanchard and Fisher 1989). Varied scales of analysis and time frames are crucial for evaluation of economic growth (Grief 2005; Saller 2005:229). In our obsidian analysis, we adopt a long time scale.

Ancient agrarian economies have profound contrasts with the modern situation in which industrial production, fossil fuels, and electronics play major roles, but growth is not thereby unimportant. Often archaeologists examine trajectories of economic change that do not necessarily imply economic growth. As one example, Sanders and Santley (1983) considered transport costs, urbanization, demography, and crafts to account for the economy of three major successive capitals in the central highlands of Mexico: Teotihuacan, Tula, and Tenochtitlan. They argued obsidian working was one key to economic power given foot transport on land and the nature of the obsidian craft. Although each of the three states and capitals had some unique characteristics, they are portrayed as repeating an economic pattern. Consideration of economic growth raises separate issues from those of economic change, such as portrayed in these three state cycles. In Mesoamerica, long-term changes in political economy have a history of important contributions (e.g., Sanders and Price 1968; Blanton et al. 1993). These perspectives have been more concerned with factors to account for the rise and demise of states and empires than economic growth and its effects on the general population. Nevertheless, some proposals have implications for economic growth.

\section{Mesoamerican proposals related to economic growth}

Golitko and Feinman (2015) examined sources of imported obsidian for a sample of sites over time using a network approach. They argued for intensified trade by the Late Postclassic period (AD 1350-1521) and chronicled a variety of fluctuations in network patterns through the Mesoamerican 
sequence. Important for our analysis, they observed that Mesoamerican obsidian distribution was never under highly centralized control by a single capital, as had been proposed for Teotihuacan (Sanders and Santley 1983; Santley 1983, 1984 1989, 2007:163-174). Thus, we would not expect coastal lowland consumers to have had their access governed by a single distant authority, and we can reasonably examine consumption as related to wider characteristics of the Mesoamerican economy.

For other researchers proposing long-term schema, the Late Postclassic period also was a time of heightened economic connections (Blanton et al. 2005:272-276). Blanton et al. (2005) see economic shifts during particular intervals in terms of the production and circulation of goods, especially "bulk luxuries." Blanton et al. (2005:274) define bulk luxuries as "costly but widely distributed goods consumed across social sectors, occupying an economic middle ground between preciosities and regional bulk goods." They include green Pachuca obsidian as a bulk luxury, although in our analysis obsidian is not treated as a luxury.

Earlier, Blanton $(1983,1985)$ proposed that the Mesoamerican market system grew following the breakup of major Classic period polities (e.g., Teotihuacan and Monte Albán) because of loosened state regulation of economic activity, paving the way for vigorous Aztec periodic markets recorded at the time of the Spanish conquest (Berdan et al. 2003; Blanton 1996). Nichols (2015) notes, however, that the Basin of Mexico after the Teotihuacan era experienced reduced market integration, contrary to Blanton's expectation.

Stark $(2000,2007)$ argued for technology transfers when particular prestigious products and associated technologies reached wider circulation, for example through prestations to people in distant communities in which social access was redefined, leading eventually to wider regional production. Cotton textiles were an example, with textiles initially portrayed mainly in imagery of Olmec leaders, but subsequently becoming widely produced in multiple regions that were environmentally suited to grow cotton. Cotton circulation to non-producing parts of Mesoamerica changed the prosperity of producing regions. ${ }^{1}$

Metalworking in late periods appears to have developed at multiple locations but not necessarily under elite control. Metal artifacts were first linked to ritual and status distinctions, with production across a wide area of West Mexico; production eventually spread (Hosler 1994, 2003). Metal-working expanded from a heavy emphasis on ritual items to at least one category functioning as a medium of exchange, "axe money" (Berdan et al. 2003:102). Therefore two contexts of technology 
transfer are indicated: those related to the "escape" of prestige items from elite restrictions and those related to industries not initially restricted to elites, or not entirely so (see Kohl [1987] for Old World cases). In Mesoamerica, technology transfers operated especially for highly valued items that were suited to long-distance exchange.

From these varied contributions about long-term economic change, we identify three issues for our analysis: the increased use of prismatic blades, growth of a vigorous market system especially in the Postclassic period, and the possibility of "inflection points" in economic growth when either a new set of systemic relationships was elaborated or relationships reoriented. A long-term perspective on coastal lowland obsidian consumption can be useful to examine the proposed changes and whether they benefited consumers generally. Because our chronology is necessarily coarse-grained, however, we do not expect to identify inflection points. Our 68 assemblages are better suited to detection of long-term trends. For the 3,500-year time frame examined, the 68 data points average under two per century, and, even with a sample double the size, we would be hard pressed to examine inflection points. We monitor the quantity of obsidian reaching coastal consumers and the transition to pressure blade technology to examine improvements in obsidian access.

\section{Evaluating economic growth in archaeology}

In an essay about economic growth in the ancient Mediterranean world, Millet (2001:19) defines economic growth as a process in which wealth at a particular scale undergoes sustained increase over time, usually measured annually, in real (i.e., adjusted for inflation) per capita production of goods and services. Adjustments are required to move such a framework into the realm of archaeological practice. Varying time intervals are substituted for annual values, usually a century or several centuries and sometimes longer depending on the scale of analysis. Too brief a time scale is usually not a problem for archaeologists, who do not struggle with distinguishing "business cycles" from long-term growth.

One issue for per capita analysis of productivity is whether to evaluate the society as a whole or consider social differentials concerning who benefits from growth. Economic growth may differentially benefit social segments and may be a process with very gradual penetration of society in the ancient world. Higher ranking, more powerful classes in complex societies enjoy better welfare at the expense of others. If we anticipate that---loosely speaking---elites likely would benefit from economic growth, a more crucial issue is whether other components of society benefit. Scheidel (2010) examined wages for poor and "respectable" wage earners using historical Old World sources for the period 1800 BC to AD 
1300 , finding sufficiently low wages across most of this span that poor households likely required inputs from men, women, and children to manage a subsistence level. His focus on independent laborers suggests this social segment seldom saw any benefits from economic growth. For ancient Rome, Scheidel and Friesen (2009) converted wage and price information to grain equivalents; they assumed subsistence rates for the estimated population in order to project grain production as a monitor of the overall economy. Little more than a subsistence level is projected for lower classes in their analysis (see critical discussion in Morris 2013:53-143). Roman economic growth remains debated (e.g., Grief 2005; Hitchner 2005; Saller 2005). Recently Jongman (2014) argued for growth from the third century BC to the second century AD on the basis of archaeological data: agricultural production, population, consumption of select ceramics and foodstuffs, and other indicators affecting most of Roman society. Likewise, Morris' (2010, 2013; Baumard et al. 2015) assessment of improved energy capture includes not only foodstuffs but also material culture for the Roman imperial core in Italy (among other societies analyzed).

The challenge for archaeology is independent assessments of agricultural production, material culture energy expenditures, and population sizes so that per capita increases can be assessed. Because exploitation of conquered populations was popular, determination of "who benefits" becomes difficult. Imperial expansion may enrich the capital or its core area, but conquered provinces may see declines in welfare. Earle and Smith (2012) compared household economic indices before and after the Aztec and Inca conquests in two provincial areas. The Mesoamerican data suggested a decline in commoner material well-being, interpreted as due to imposition of another taxation level on pre-existing local obligations under hegemonic rule. For the Inca case, households showed improved economic well-being under a contrastive political economy that imposed more direct rule and reorganization of the economy, with reduced privileges for local elites. Our study does not attempt to focus on areas undergoing wider political incorporation nor to adjust for a core state context versus a more marginal provincial position. Instead, we opt for a wide geographic array of coastal lowland sites representing non-elites and enough representation in different periods to assess long-term patterns. We next remark on additional monitors of economic growth, following Millet's (2001) lead.

Specialization, exchange, and urbanization

Some scholars (e.g., Hopkins 1983; Jongman 2014; Persson 1988) look for evidence of greater specialization implying a growing diversity and amount of products and their wider circulation (Millett 2001:28-29). The demand met by a specialist could reflect more consumption unless population growth 
or population concentration provided more consumers or made them more accessible because of lowered transport costs. Some regions may become specialized to a degree in particular technologies and products, such as cotton, which is an example of Hopkins' (1983:xv, xvi) notion of increased division of labor and an increase in non-agricultural production. Increased specialization does not guarantee economic growth per capita, but it is likely to accompany it.

Closely related to specialization is burgeoning trade, especially with distant regions, implying more specialization, more economies of scale, and hence economic growth, especially when trade stimulates economic changes in distant regions (Millett 2001:30-31, 34-35). Imperial expansion can have such effects, providing a secure framework for long-distance exchanges (Millett 2001:37). Mesoamerica experienced a succession of episodes of heightened long-distance contacts and exchange. Well-known examples include Early Formative Gulf Olmec interactions, the long-distance activities of Classic period Teotihuacan, the Postclassic Mixteca-Puebla International style, and the Late Postclassic Aztec empire. Documentary indications of media of exchange in Late Postclassic Mesoamerica (at least in the Aztec imperial core) are a signal that the volume of marketplace exchanges had risen to a point that media became convenient (axe monies, cacao beans, cotton mantles) (Berdan et al. 2003:102). The issue here is the extent to which such episodes of increased interaction led to economic growth.

Growing urbanization is another monitor of economic growth, with the reasoning that cities promote specialization and economies of scale due to their exchange opportunities with reduced transport costs (Millett 2001:35). ${ }^{2}$ Numerous craft specializations at Classic period Teotihuacan in Mesoamerica show this link because Teotihuacan was one of the largest cities of its time world-wide (Cowgill 2015:165-188; Nichols 2015). Teotihuacan also displays an array of foreign contacts, some of which likely were linked to Teotihuacan imports from distant regions (e.g., Manzanilla 2015), demonstrating heightened trade. The extent to which households at Teotihuacan enjoyed any improvement in access to everyday items has not been evaluated. Health appears to have suffered, at least for poorer urbanites (Storey 1992:35-44, 238-266), which is one measure suggesting a decline in standard of living.

A degree of stability

Another consideration for economic growth is contextual. Over decades or centuries, a degree of political stability benefits exchange (Hopkins 1983). Mercantile activity and linked economic specialization are dependent on access to consumers and on moderation of risk that attends any 
diversion from food production by the producer or trader (Spielmann 1986). The Mesoamerican tendency toward specialization at the household level, sometimes including multi-crafting (e.g., Feinman and Nicholas 2000), is one signal that risk was controlled through mixed strategies. The accumulating Classic period evidence for marketplaces and market systems (e.g., Carballo 2013; Feinman and Nicholas 2010; Masson and Freidel 2013; Stark and Ossa 2010), may point to a "unity dividend" due to long-lived states such as Monte Albán and Teotihuacan.

The Late Postclassic is distinguished by an interlocking market system under Aztec rule, suggesting that market institutions became well-established during the Postclassic period (Blanton 1996). Whether this situation accompanied an improved general standard of living and economic growth requires monitoring at the household and settlement scales in different regional and social contexts, an effort toward which we contribute in our coastal obsidian study.

\section{Residential consumption}

We focus on residential consumption like other authors who sidestep measurement of the production and distribution of goods and services in favor of general human welfare, such as health, longevity, access to education, or to material items (Millet 2001:20-21). This approach drives directly at the issue of per capita benefits. Archaeological remains, including artifacts, architecture, food remains, osteology, and bone chemistry, can shed light on welfare along various dimensions. Many of these data reflect household consumption of labor or goods, and some reflect individual consumption of foods in terms of health. End point consumption is one of the strengths of household/residential archaeology (Blanton 1994:7; Wilk and Rathje 1982:624). Morris (2005) discusses the potential roles of archaeological evidence along with its hazards and provides an Aegean regional example of increasing house sizes, 800-300 BC.

Consumption offers a way to circumvent addressing inflation (incommensurate values) if we look for indications of greater material well-being over time. In a sense, we can ask if a roster of household items improves over time. A roster approach is an archaeological device somewhat akin to the basket of goods concept in modern efforts to establish international currency equivalencies ("purchasing power parity") or to monitor inflation (e.g., Asea and Corden 1994; Boskin et al. 1998; Rogoff 1996). The idea of a roster of household items differs from the economists' basket of goods because it does not have a fixed content, useful to compare currencies. New items can be added, and amount, quality, or diversity of items can be assessed. 
Analysis of an archaeological roster or particular items per capita requires a population figure parsed to different residential locations over reasonably narrow intervals. Proxy measures usually are required for per capita analysis in archaeology. In one exception, Clark et al. (1989), for the Formative Pacific coast of Chiapas, use general population estimates for the region and the amount of obsidian per cubic meter of excavation over time to represent consumption. An objection to standardization by cubic meters of excavation is the variation in formation processes, especially among sites and regions. We use a different proxy, pottery counts, as will be discussed. Ceramic proxies have been used in other obsidian studies (e.g., De Leon 2008; Hedgepeth 2010; Levine 2014; Parry 1987:24; Santley 2007:165). We return to the issue of standardization by volume of excavation in the discussion of results.

In sum, there are multiple possibilities to assess economic growth. Our approach is results oriented: whatever changes transpired elsewhere or locally, we ask whether there are general trends in obsidian consumption and if they can be interpreted as an ingredient in economic growth. Ideas about Mesoamerican obsidian and its roles have been highly varied, however, and discussion of the nature of obsidian implements is next.

\section{Mesoamerican obsidian: descriptive and interpretive background}

The widespread distribution of obsidian implements or cores from sources in the Mexican and Guatemalan highlands has attracted archaeological attention and figured in broad claims about the economic and political roles of obsidian (see Clark [2003] for a historical review of Mesoamerican obsidian studies). Smith (2003:118-119) classified obsidian as one of the key Postclassic Mesoamerican commodities due to its circulation as raw material, domestic tools, and industrial tools. Some obsidian products or by-products had a variety of ritual and symbolic qualities (see Levine and Carballo 2014; Pastrana and Athie 2014), which underscores the diverse roles of obsidian in Mesoamerica as well as its overall importance. Here we are not concerned with rare, specialty obsidian products, including eccentric knapped pieces, ground and polished ear spools, ornamental spangles, or large bifaces, such as sacrificial knives. Rather, we focus on the flakes or prismatic blade fragments that were found at households across Mesoamerica in all regions and major periods, used for a variety of tasks including slicing and scraping.

Obsidian has a long history of use. It was procured by seasonally mobile coastal foragers as early as the Middle and Late Archaic periods (Mountjoy et al. 1972; Nelson and Voorhies 1980; Voorhies 2004:369-380; Wilkerson 1975). Obsidian became a principal material for chipped stone industries at 
the earliest coastal villages and centers during the Formative period, a role that continued through the prehispanic sequence. Percussion and bipolar flake technology is recorded in early coastal assemblages before pressure blade technology became dominant (Clark 1981, 1989; Hepp 2015:251-257; Hirth et al. 2013; Paris 2015; Williams 2012). It is a technically undemanding method compared to pressure prismatic blade production. In bipolar knapping a core or other fragment is struck on a hard anvil with a percussor (Bokesenbaum 1980; Clark 1981, 1989), producing some usable pieces and a lot of shatter. Bipolar knapping can wring the most usable flakes from small nodules or remnant larger pieces, a conservation strategy, but De Leon's (2008) analyses of the percussion industry at San Lorenzo demonstrated that bipolar reduction tended to occur towards the end of percussion flake removal from small nodules that rested on and overhung an anvil. He notes the flake industry proved more highly disciplined and complex than nodule smashing would imply, and it included production of small flakes suited to create wedges.

Prismatic pressure blades were produced and exchanged early in Mesoamerica, including the coastal lowlands, for example, appearing in the Chicharras phase at San Lorenzo, Veracruz, 1500-1400 cal B.C. (Hirth et al. 2013:2789). Blades reached highland Oaxacan Early Formative sites, although chert was locally available (Parry 1987:39-41). Early blades were scarce to non-existent in distant locations at first, but during the peak of San Lorenzo, for example, they rose to $31.4 \%$ of all obsidian ( San Lorenzo B phase, 1200-1000 cal BC, Hirth et al. 2013:2790), showing the prominence of this early center in longdistance exchange. Other Early Formative coastal locations did not have as much blade access, as we will show.

Gradually, prismatic blades, with their more consistent morphology, became the most common knapped implement in both the coastal lowlands and the highlands, with percussion flaking mainly relegated to other roles, such as biface production, polyhedral core pre-forming, and re-sharpening of tools. The emphasis on prismatic blades meant that obsidian deposits with few impurities were favored. Eventually, polyhedral cores were exported to lowland sites, allowing pressure blade production closer to consumers and perhaps more attuned to local demand. Specialized prismatic blade workshops have been detected (e.g., in the Gulf lowlands, Barrett 2003; Heller 2000; Stark 2007). With imported cores, some lowland sites will contain core maintenance debitage or other production indicators. Polyhedral core preparation debris always would be at or close to highland quarries. Even when blades and prismatic technology were commonplace, some exhausted cores were further reduced through percussion or bipolar knapping. Percussion, pressure, and bipolar knapping were techniques for 
particular ends, and the transition from predominantly percussion and bipolar flake knapping to pressure prismatic blades was one of emphasis, not exclusion.

As blades or flakes, did obsidian contribute to wealth (Smith 1987)? Was it a "bulk luxury" (Blanton et al. 2005; Kepecs 2003:130)? Was it utilitarian (Braswell 2003)? Was it a household necessity (Rathje 1972:389-390)? In the coastal lowlands, we argue it was utilitarian, serving many everyday functions even if also used in ritual for bloodletting, as offerings, or in composite blade weapons. If not a necessity for survival, obsidian tools at least were highly useful and desirable. Even in the Maya lowlands (Yucatan peninsula) with local chert supplies, imported obsidian was relatively common (Nelson and Clark 1989:299-303; Rathje 1972:389-390). We next discuss interpretations of obsidian in more detail to justify our utilitarian interpretation.

\section{Obsidian and wealth or welfare}

Crude blades appeared in the Late Archaic period at the Santa Luisa site in northern lowland Veracruz (Wilkerson 1975) ${ }^{3}$, but typically coastal locations had only flake and bipolar industries in Archaic sites. These were not contexts with wealth differentials. Initially prismatic blades but not prepared cores were imported to lowland sites in the Early Formative period, such as at San Lorenzo, Veracruz (Hirth et al. 2013). Obsidian prismatic blades were routinely subdivided to snap off a curving distal end and the thicker bulbar proximal end. Intervening segments, also often subdivided, have the advantage of straight mostly parallel sides, whereas flakes are more irregular. The utility of prismatic blade segments could be a basis for wealth differentials if blades were quite scarce, but studies both in the coastal lowlands and elsewhere have pointed to the wide social distribution of blades, with many ordinary households obtaining some of these imported tools; differentials are more common among settlements in a site hierarchy (see note 1 ).

Other perspectives on differential access involve how heavily blades were used before discard. Usewear studies have varied so much in methods, e.g., magnification, that the degree of use of obsidian edges is hard to compare. Often, however, the edges do not seem to have been so scarce that, after use on softer materials, they routinely ended up retouched or used in activities that yielded heavy usewear--and many do not show usewear (e.g., Aoyama 1995; Brodbeck 1993; Clark 1988:33-42; Hirth and Castanzo 2006:219-233; Knight 2003: 83-84; Lewenstein 1981, 1987:133, 137-147; Parry 1987:73-74; Robles Fernández 2004:212-216). Other traits than abundance of obsidian tools or amount of usewear may demonstrate differential access, such as heavier prismatic blades (Knight and Glascock 2009:518), 
wider blades (Hirth and Castanzo 2006:232; Parry 1987:115), or green obsidian, which was valued for its color and perhaps also symbolic connections to a powerful center that controlled the Pachuca source (Ball 1983:133; Knight 2003:86-87; Knight and Glascock 2009:521; Levine 2014:176-177; Rebnegger 2010:86; Santley 2007:164-165; Sharer 1983:241). We do not address these varied ways to identify differentials in obsidian access because we lack appropriate data, and because we concentrate on nonelite contexts. Our view of obsidian as utilitarian is compatible with Smith's (1987:309-310) view that household utilitarian equipment is so widespread in agrarian societies that it is not likely to discriminate wealth. That flakes and blades were not wealth items does not mean that they were not valued or that local demand was entirely satisfied at particular times and places.

Assemblages on the Pacific coast of Chiapas show that demand for blades and flake technology are related. The Tajumulco ignimbrite (similar in appearance to obsidian, a welded volcanic tuff with inclusion irregularities) was suited to flake production rather than prismatic blades and dominated the Pacific coastal Archaic assemblages (Clark et al. 1989:273). It also resurges during the Protoclassic and Early Classic periods when blade access diminished; more use of Tajumulco material recurred, along with scavenging of archaeological obsidian, after the Spanish conquest interrupted prehispanic distribution networks (Clark 1989:222-223; Clark et al. 1989:278-279). Thus, as blade access declined, demand was not satisfied, and percussion flake and bipolar technology was an economizing response. Similarly, in the Copan Valley, rural households poorly served by blade distribution relied on a cobble and flake industry, which was present before blades or blade cores were imported to local centers; the cobble and flake technology again became prevalent when blade access declined (Aoyama 2001). Clearly flakes were a less desirable choice than prismatic blades, likely for functional reasons. Prismatic blades have a relatively standardized and substitutable form that also lends itself to hafting blade segments.

Prismatic blade demand likely had elasticity, as freshly detached blades would have had the sharpest edges, but used blades could still have been functional. Distance to good obsidian sources for blades or preformed polyhedral cores may account for differences in consumption, but we set this issue aside for future consideration. In sum, blades were more desirable for functional reasons than flakes, and blade access was not always satisfied, depending on the social segments, tasks, and geographic locations considered.

\section{Obsidian as a bulk luxury}


The phrase "bulk luxury" was first applied to Yucatecan salt (Kepecs 2003:130). Blanton and colleagues (2005:274) consider green obsidian to have been a bulk luxury, but Golitko and Feinman (2015:238-239) expand the concept to obsidian generally for the Classic and Postclassic periods, describing it as one of the goods that was "a non-essential, but valued, commodity (since chert and other cutting materials are much more broadly accessible) widely available to all segments of Mesoamerican society." The notion of "non-essential" is slippery, and people without local stone in the coastal lowlands would surely disagree with Golitko and Feinman. In such regions, access to obsidian was common from the Late Archaic period onward, but access to chert generally was not. We do not characterize obsidian as a bulk luxury for the coastal lowlands, but as a utilitarian long-distance exchange item, used for a variety of domestic activities. Generally, lithic analysts tend to view obsidian flakes and blades as utilitarian, not luxury items (e.g., Aoyama 1999:197; Braswell 2003; De Leon 2008).

\section{Obsidian versus chert}

As noted, obsidian was not the only raw material that could be knapped to produce sharp cutting edges and formal tools. ${ }^{4}$ Many regions had chert available, a cryptocrystalline material excellent for knapping---for example, the Maya lowlands, the upper Grijalva drainage in Chiapas, the Mixteca Alta, and the Valley of Oaxaca (Clark 1988; Lewenstein 1987; Parry 1987; Shafer and Hester 1991). Lithic industries in these locations emphasized chert numerically because the raw material was local and well suited to making a variety of bifaces, flakes, or blades, even though some obsidian was imported (Nelson and Clark (1998:299-303).

Chert is not as brittle as obsidian and provides a tougher material for bifacial tools of various kinds (Hirth and Castanzo 2006:219; Lewenstein 1987:77). Obsidian produces sharper edges than chert, feathering out to be sharper than surgical steel (Buck 1982). In Oaxaca, obsidian was preferred for cutting soft materials, given its acuity, and chert, for heavier tasks (Parry 1987:73). These two materials are not entirely interchangeable, but both are versatile. Parry (1987:73) found use damage indicating that both materials performed the same range of tasks. Chert from Colha was exchanged in part of the Maya lowlands (Shafer and Hester 1991), but exchange of chert raw material or tools was never as widespread in Mesoamerica as exchange of obsidian, as our data document (Table 2). The value and roles of imported obsidian are likely to differ where a good stone alternative is available. For that reason, we standardize our comparison by focusing on the coastal lowlands, excluding the Yucatan peninsula, and we assume considerable demand for basic cutting or scraping tools, satisfied only through long-distance exchange. 
In sum, obsidian is processed with technologies that are sensitive to the abundance and purity of the raw material as well as the functional properties of the knapped products. As long-distance exchange networks became more active with more frequent trade of varied items, individual products could become more widely accessible, given that multi-purpose trips reduce the transport costs for a single item. As Clark et al. (1989:280) point out, producers of prismatic blades do not necessarily have an incentive to satisfy coastal demand. Increasing blade production, eventually including circulation of preformed cores, is dependent on an exchange system with multiple product movements among regions. Lowland products suitable for export are numerous, including cotton, cacao, and colorful feathers. An incremental growth in obsidian blades reaching coastal consumers is compatible with expanding Mesoamerican exchanges and their increasing regularity.

\section{Sample of assemblages and variables}

We examine obsidian consumption for 68 archaeological assemblages from the Gulf and Pacific lowlands of Mesoamerica (Tables 2, 3). The assemblages represent 28 sites and are reasonably well distributed across the major periods considered. Some span adjacent periods, and some are identified with a local phase. All assemblages are excavated and represent household trash (Supplemental Table 1). The depositional contexts vary; middens, floors, fill, and trash pits provide residential materials. The contexts are screened with a maximum mesh size of $1 / 4$ inch because obsidian artifacts are small and disproportionately overlooked in unscreened excavations. Excavations are used for the analysis rather than surface collections because variations in surface visibility and the possible underrepresentation of obsidian in surface collections make survey assemblages less reliable for comparisons among multiple sites and locales. Our focus is on comparison among sites across time periods, not depositional variation. Our analysis is better served by pooling several strata or contexts from a residential locus or site to give an overall summary quantity for a phase or period. More obsidian likely was disposed in trash pits, middens, or fill because it was hazardous for foot traffic, while less of it remained on floors or surfaces. Combining such deposits for a phase or period at a site or residence helps even out the vagaries of formation processes. Pooling individual contexts is often necessary to obtain a robust sample size of artifacts, as obsidian is infrequent compared to sherds. We used a minimum of 100 rims for assemblages, but include one case with 99 rims. We do not confine our analysis to only deposits that yielded obsidian for the same reason of avoiding depositional biases as much as possible and achieving an overall profile of consumption. 
An important consideration is our focus on non-elite households. To understand how obsidian consumption changed over time and evaluate economic growth, we are more interested in ordinary households than elite households. We have therefore avoided deposits from palatial residences or trash from major ritual structures because of the possibility they do not reflect obsidian consumption for the general population. In three cases, investigators considered residences to have been those of local elites, but because the residential mounds were not remarkably different and obsidian values were not obviously distinct from other values, we left them in the dataset. The notion of "elite" in different archaeological contexts is a relative matter. Some of the assemblages are from prosperous households yet were not among the most elite stratum, and some represent residences at major centers that may have provided improved obsidian access, but these situations contribute to the overall profile of nonelites in the coastal lowlands. When we complement examination of overall trends with a closer look at particular periods, e.g., the Postclassic, the sample size is reduced and variability in social contexts or regions becomes more problematic.

We have excluded specialized blade production sites, but we accommodate some household knapping for domestic consumption. Households commonly produce many items for their own use or for occasional reciprocal social exchanges. Households may modify blades or exhausted blade cores to make other tools. With the importation of polyhedral cores to the lowlands, mainly specialized craft locations produce core maintenance debitage, error recovery blades, and other by-products. Blade consuming households will have few if any such fragments.

\section{Obsidian count and weight}

Two variables represent the quantity of obsidian in the assemblages. Obsidian count is relevant because the common implement forms are blades and flakes. Blade segments, although they exhibit variation is width and length, are not wildly different in size, nor are flakes, because the early nodular cores for flakes generally were not large, therefore not producing large flakes. Count is sensitive to the production techniques that were typical, and flake and bipolar household industries produce much more debitage than coastal prismatic blade removal from polyhedral cores or the importation of blades. Counts will therefore be elevated for assemblages in which household flake and bipolar methods predominated.

Weight of obsidian is an important cross-check on the results of obsidian count. Obsidian weight (in grams) is useful to capture the amount of raw material in different assemblages, taking into 
account that some pieces are small unusable debitage, and some pieces are much larger core fragments or other large pieces. Early flake-dominated assemblages should have higher weights of obsidian because more of the raw material is wasted in the knapping process. Prismatic blade technology is renowned for its efficient production of total cutting edges from a given weight of preformed core material compared to flake knapping (Sheets and Muto 1972).

Rim and total sherd counts: the population proxies

Because we do not know the population size of sites or residential locations during particular time intervals, we substitute another artifact category that is not scarce: fragments of pottery vessels. Clay is variably suited to making pottery, but no major region of Mesoamerica is lacking in local raw material for making and firing pots. Presumably, then, demand for cooking, storage, and serving vessels was readily met, whether through auto-production by families or by local exchange. This is not to say that some categories of vessels may not have been of special value or were not exchanged beyond the local area. We assume for the purposes of our analysis that the count of rims or of total sherds from the assemblages will provide a rough guide to the deposition of broken pottery fragments, which would proceed at particular paces for different functional kinds of vessels according to the number of people consuming food. Rim count has the advantage of a more balanced representation of serving vessels versus large storage or cooking jars because bowl versus jar apertures do not vary as much as total sherds for these forms. Of course, breakage rates vary for different vessels, depending on thermal stress or amount of handling. For sedentary agricultural populations preparing the suite of Mesoamerican domesticates, we assume general similarities in the functional pottery tool kits. ${ }^{5}$

Not all projects compile rim counts, but sometimes total sherd count is available (or vice versa). Both measures are useful as a "stand-in" for population. We rely on pooling of different depositional contexts to moderate varying sherd trituration. Scant breakage will particularly reduce the total sherd count because many potential sherds remain attached to rims. Noteworthy unaccounted variation among sites in obsidian consumption would be one possible sign of a high level of variation in sherd breakage, formation processes, or proportions of kinds of vessels that cause ratios of obsidian to pottery to be unstable. Certainly we can expect some variation due to these factors as well as to social contexts (center versus countryside) and distances to sources, but we hope this variation will not overwhelm trends in obsidian consumption.

Pottery tool kit change 
If the pottery tool kit enlarges over time, then ratios of obsidian to rims or total sherds are not good measures of consumption---unless corrected. Suppose people in two successive periods have equal access to obsidian. If the second period has an enlarged pottery tool kit, then obsidian will seem scarcer relative to rims or total sherds, which will have increased in numbers. Under such conditions, standardizing by volume of excavated deposits provides the only way to evaluate changing ceramic patterns in a manner comparable to other classes of data (e.g., Rosenswig 2009).

The two most likely sources of change in the pottery tool kit are (1) increasing hierarchical differentiation in societies and (2) changes in cooking technology. With the growth of social hierarchies and hosting or display to communicate social position, we are likely to see a disproportionate increase in the number and kinds of serving vessels, but jars would likely increase less because they function less in social displays and their large sizes can accommodate a degree of food and drink preparation for hosting.

Thermal stress on cooking pots is one of the most important causes of breakage and consequent production of sherds. There are two parts of the sequence in which changing cooking practices are a concern, one of them early in the sequence and one of them late. Stone boiling changed to direct heat as the Formative period began, with augmentation of the numbers of neckless jars. Also, at specialized temporary sites during the Formative on the Pacific coast, neckless jars were used to boil saline water in salt production. ${ }^{6}$ We largely avoid the latter cooking distortion by examining sedentary sites.

A second major change in cooking practices was the growing use of comales (large flat griddles) for toasting tortillas (and seeds), especially during the Postclassic period. Comales break readily and, relative to jars, yield numerous rim sherds compared to body sherds. Because of the change toward more comal use, we monitor the ratio of rims to total sherds. For those assemblages with both rim and total sherd count, a higher ratio likely indicates more bowls or comales, and a lower ratio indicates fewer bowls or comales (or both). If obsidian consumption appears to decline over time, but the ratio of rims to total sherds increases, we can suspect that the decline of obsidian relative to pottery is actually an effect of augmentation of the pottery tool kit.

Other pottery distortions are possible. For example, If vessels in general or key classes of vessels, such as jars, increased or decreased in size, the rim to total sherd ratio likely would be affected because body sherds would likely respond disproportionately. We have no evidence of major size changes of this sort, but in future researchers might detect such changes. 


\section{Summary}

For the four primary variables described above (obsidian count and weight, rim and total sherd count), we generate five derived variables (ratios of obsidian count to rims, obsidian weight to rims, obsidian count to total sherds, obsidian weight to total sherds, and rim count to total sherd count). None of the contributors in this joint study collected their data expressly for it, and there are several cases with missing data for a particular primary variable, with, therefore, missing data for derived variables. Problems with missing data are another reason that both obsidian count and weight and both rim and total sherd counts are part of the study.

\section{Expectations}

If Mesoamerica experienced economic growth, we expect access to imported obsidian implements for lowland consumers to have improved over time. Because predominant obsidian technologies shifted during the Formative period, we expect a progressive transition in early periods to prismatic blade technology because of its efficiency in yielding cutting edges and the greater utility of prismatic blades for many cutting and scraping tasks; this shift would have been realized as growth of exchange systems improved distribution of blades and eventually preformed polyhedral cores.

Because of the technological shift to prismatic blades and the differences in the coastal byproducts associated with each technology, count and weight of obsidian are likely to decline as prismatic blades substitute for percussion and bipolar flakes. An apparent decline in access to obsidian may mean improving access to a preferred new technology. To monitor this transition, we compiled data concerning the percentage of prismatic pressure blades in assemblages, including as many from our dataset as feasible and adding recent information for the site of San Lorenzo, Veracruz (Hirth et al. 2013) (Table 4).

Our blade counts are only approximate because projects do not employ exactly comparable technological classifications. For example, most counts will represent entirely or almost entirely third series pressure blades, but other pressure blades (first series, second series) or ribbon blades may be counted. First and second series blades both show some dorsal scars from polyhedral core preparation, but third series blades, the main objective for consumers, are removed subsequently and therefore are more regular (Clark and Bryant 1997). Blades related to core maintenance, such as error recovery or ribbon blades, may be included in some counts, but they are few at consumer households. Data are not always available concerning blades used to make other obsidian tools, such as projectile points or 
scrapers. Such tools may have been made from blades at consumer households and could represent some of their blade access. Details concerning blade counts appear in Supplemental Table 2. Tools from blades do not appear to be a major distortion of blade percentages. We had to pool some assemblages in order to match obsidian counts to available blade counts. Despite these limitations, the general picture of blade consumption is reasonably well characterized in Table 4.

Improvement in obsidian access is anticipated in the Postclassic period if the indications of vigorous markets and long-distance exchanges attested in documents represent increased production and better distribution of prismatic blades across Mesoamerica. If so, we expect that the blade count and weight ratios to rims or to total sherds will increase by the Late Postclassic period and possibly earlier. This expectation may not be overtly displayed if the pottery tool kit enlarged with more bowls used in hosting and social displays or with more comales for cooking. To assess changes in the pottery tool kit we examine rim to total sherd ratios. If this ratio holds steady, we do not have a case for a distortion of the obsidian ratios.

\section{Comments about production expectations}

Some possibilities concerning blade production and distribution to costeños are not addressed in our study, for example, preparation and movement of preformed polyhedral cores to coastal locations instead of finished blades. We do not monitor the manner in which blades arrived to consumers (see De Leon et al. 2009).

Other technological advances may have improved production, such as grinding the platform of blade cores. Platform grinding was particularly common during the Postclassic period (Healan 2009). Healan (2009:107) notes ground platforms offer better purchase of the bit used to press off blades, and the minute surface irregularities may ease crack initiation in detachment. Healan (2009:106) estimates that $13 \%$ of raw material was expended in the additional steps in platform grinding and argues there must have been a noteworthy incentive to warrant the material and labor costs. In his view the combination of low obsidian blade consumption in households and low production rates in multicrafting households kept many producers from maintaining peak motor skills, and platform grinding improved their success in blade detachments. Healan (2009:108) also notes a highly specialized production location where grinding was applied to cores, which indicates platform grinding was attractive for more intensive production as well. Overall, Healan (2009) and Darras (2008) see the Postclassic as the period when obsidian blades became more plentiful than ever before. 
Evidence for platform grinding is variable in time and space, although it is generally a late phenomenon in the Mexican highlands (Healan 2009:104). A more precise examination of the role of platform grinding in the obsidian economy is beyond the scope of this paper, but we provide data (if available) concerning prismatic platform grinding in our Postclassic assemblages to assess if coastal populations were tied into this technological change (Supplemental Table 1).

\section{Comments about consumption expectations}

Unsatisfied demand for cutting edges has been evaluated previously in terms of obsidian "falloff" patterns, that is, decline in quantity with distance. Tolstoy et al. (1977:101) considered sites during the Formative period in the Basin of Mexico, but the effect is mainly observable for one distant site, Coapexco. Sidrys (1977) examined cutting edge per weight for Maya sites, proposing greater scarcity at greater distance (due to transport costs) that led to more economizing in blade widths (narrower), which was observed in his data.

Findings for Maya sites on the Yucatan peninsula concerning increased obsidian consumption complement those for our coastal assemblages. Sidrys (1977:101) noted increased obsidian trade in the Postclassic Maya lowlands compared to the Classic period, using considerations of distance from sources and the ratio of obsidian to sherds. Using four Maya lowland sites with sequential information, Nelson and Clark (1998:302-303) show that obsidian increased in relation to chert between the Formative and Classic periods, with some indications of further increase in the Postclassic period.

Yet other estimates have focused on per capita blade consumption over time. As noted, Clark et al. (1989) examined obsidian consumption in terms of obsidian per volume of excavated deposit for the Pacific coast of Chiapas, chronicling ups and downs in the supply of blades relative to population. For the Central Mexican highlands, Healan (2009:108) summarized four excavation estimates of per capita blade consumption in four sequential time periods that indicate rising consumption from two blades per person during the Late Formative period to seven blades per person during the Early Postclassic period.

These prior investigations show: (1) particular regions may experience variation in obsidian supply, and (2) an increase in obsidian consumption may have occurred across the Mesoamerican sequence. Our coastal lowland study attempts to evaluate consumption over a long span with a larger dataset than previous studies.

\section{Results and discussion}


Our expectation is that obsidian access improved as prismatic blades became more common, but the ratio graphs show declining obsidian count and weight relative to pottery during the Formative period (Figure 2) reflecting the gradual technological transition from predominantly percussion flake and bipolar knapping to prismatic blade technology. ${ }^{7}$ To independently monitor the transition to prismatic blades, we compiled the percentages of blades in our dataset assemblages plus some published data (Table 4). Table 4 shows that the earliest coastal assemblages lack prismatic blades, but they begin to appear in the southern Gulf lowlands during the Early Formative period where the major center of San Lorenzo was located. Blades were more widespread in the lowlands during the Middle and Late Formative periods, although variable in percent, reaching between $40-70$ percent of obsidian in the Terminal Formative. By the Classic and Postclassic periods, most assemblages with a good sample size range from 60-98 percent. Regional political economies loom large in obsidian prismatic blade access especially during the Formative transition process. The overall implication of Table 4 is that the count and weight of obsidian should decline during the Formative period, although somewhat unevenly, because importation of prismatic blades varies geographically.

Flake and bipolar technology produces so much debitage (by-product fragments) and such variably shaped cutting edges that comparisons of ratios of obsidian counts and weights to rims or to total sherds are incommensurate for percussion flake versus prismatic blade dominated assemblages. If we knew what proportions of flakes were usable (or for what tasks), we would be in a position to make more effective comparisons to prismatic blades (assuming imported nodules for flakes were roughly comparable in size at different sites). Although prismatic blades can be fairly easily assessed for amount of usable cutting edge, highly variable flake and bipolar fragments are more difficult to evaluate. Further, we are unable to specify exactly how the more uniform morphology of prismatic blade segments translates into functional advantages over flakes that had irregular morphology.

The switch to prismatic blade technology was not only a matter of morphological utility, but also a considerable savings in transport of raw material. Finished blades were sufficiently valued that they were at times imported, but finished flakes were not, so far as has been discerned. The technological transition to prismatic blades improved the situation of households with respect to access to more desired obsidian cutting edges, even if access remained imperfect in some times and places.

Pottery may enhance the early high ratios of obsidian to ceramics in addition to the reliance on percussion technology. The Initial and Early Formative pottery tool kits may have been lower in the 
numbers (and kinds) of vessels compared to those later in the Formative period and especially the Classic period. For many Initial and Early Formative assemblages, tecomates (neckless jars) and bowls and dishes were the main forms. At the Cuauhtémoc site Rosenswig (2012:228) shows that, from the Initial Formative to the Middle Formative, "other" vessels become a noteworthy percentage of the inventory in addition to these two major categories. This observation does not establish an absolute increase in the pottery tool kit, but it is suggestive that one may have occurred. To examine this possibility in future, rims or sherds per volume of deposit over time may afford a means to assess an increase in the quantity of vessels, despite the challenge of variation in formation processes among sites and regions.

Only a few outliers are evident on the Figure 2 graphs. None of the outliers is especially divergent but the three assemblages involved (assemblage 6 from Cuauhtémoc, 34 from Izapa, and 46 from Palo Errado are also outliers in a more marked fashion on other graphs. The earliest outlier in Figure 2a, assemblage 6 from Cuauhtémoc, may simply represent some of the variation in quantities of obsidian in different deposits, as it is only slightly higher than assemblage 1 from the same site. Assemblage 6 is also an outlier on Figure $2 d$ involving obsidian weight. The anomalous patterns of these Ocós-phase deposits may be due to sample size, as other artifact patterns are inconsistent with Initial Formative trends at Cuauhtémoc (Rosenswig 2010: 154, 160-161). The second outlier on Figure 2a is assemblage 34 from Izapa, which is also an outlier on Figures $2 b$ and $2 d$. The materials from this large center suggest unusually favorable access to obsidian. The final outlier on Figure $2 \mathrm{a}$ is assemblage 46 from Palo Errado, derived from excavations at a local higher-status residence with some evidence of knapping; however, assemblage 45 from that site has similar characteristics and is not an outlier, nor is assemblage 47 that also represents local elite, but without indications of knapping. Consequently, assemblage 46 seems to be particularly enriched in obsidian due to residential knapping, representing some of the variation in intensity of particular activities or in formation processes.

In Figure 2b, showing the ratio of obsidian count to sherd count, the earliest outlier is dramatic, assemblage 5 , Conq 18 . This assemblage has an extremely low ratio. There are residential traces in the excavated deposits but also considerable evidence of salt production through boiling (Neff 2014). This activity in other seasonal Pacific coastal sites skews their inventories with large numbers of tecomates and little or no obsidian (see note 4). Consequently, this outlier reflects the particular activity profile of the site. The outliers are reminders that households are not uniform in their activities and that obsidian 
consumption consequently varies. See De Leon (2008:412-413, 417-418) for additional examples of household variability.

After prismatic technology became widespread, Figure 2 graphs do not suggest any change in access and consumption during the Classic or Postclassic periods, but subtle change may be masked by the accommodation of high values from the Formative period when flake and bipolar technology was particularly important. We separately examine the Classic and Postclassic periods for trends in Figure 3, but we see no clear indication of improving access through the Classic period. In none of the Figure 3 graphs are the Postclassic period values consistently higher than most Classic period values in amount of obsidian relative to pottery, although one or two values may be higher.

Figure $3 \mathrm{~b}$ shows that the ratios of obsidian count to sherd count vary considerably for the Classic and Postclassic periods, likely reflecting differences in sherd trituration and obsidian fragment size. Nevertheless, the Postclassic appears to have several relatively low values, contrary to the notion of improved access, which is even more apparent in the graph of obsidian weight to sherds (Figure 3d). Do changes in the pottery tool kit distort our perception of obsidian access because comales came into wider use during the Postclassic, boosting rim counts relative to sherd counts (Tables 2, 3)? We will turn to the graphs of rim count to sherd count in Figure 4 after commenting on the outliers on Figure 3 graphs.

In Figure 3a, a single outlier derives from assemblage 46, Palo Errado, already discussed in connection with Figure 2. In Figure 3d, assemblage 53 from Miguel Alemán is an outlier with higher obsidian weight relative to sherd count. This outlier reflects the effects of a small obsidian count ( 3 pieces) with relatively high weight. The second outlier in Figure 3d is from assemblage 60, Chacalilla, also high in obsidian weight, but with a robust sample. Chalcalilla is well supplied with obsidian and has workshop deposits related to blade production elsewhere at the site. Thus for Figure 3, as with Figure 2, there are a few outliers, but for the most part they reflect interpretable variability in the sample. They do not bear on the observation that Postclassic ratios show some signs of decline, requiring us to consider the ratios of rims to sherds next.

Graphs of rim count to total sherd count (Figure 4) allow us to check for the effects of increasing numbers of bowls or comales that generate fewer nonrims, compared to other forms. In Figure 4a, the graph of rim to sherd count for all periods shows remarkable consistency over time, with a few outliers, as will be discussed. Figure $4 \mathrm{~b}$ focuses on the Classic and Postclassic periods. Three striking outliers 
(assemblages $53,56,57$ ) have an unusually high proportion of bowls, based on form studies in those projects. In two of the three cases $(56,57)$, trituration was exceptionally low in middens, reducing the number of non-rims. A revised graph eliminates the three outliers (Figure $4 \mathrm{c}$ ) and shows considerable variation. Although not so extreme as the outliers, three higher values in the Early Classic period derive from prosperous residences that may have used more bowls socially (assemblages 38, 39, 40). A high ratio from Postclassic Gonzalo Hernández (assemblage 66) on the coast of Chiapas reflects its relatively high percentage of comales (Supplementary Table 1), although comal percentages from households at Tututepec (assemblages 61, 62, 67) are as high or higher but yield a rim to sherd ratio somewhat lower; Tututepec ratios are still among the higher ones for the Postclassic assemblages.

For expectations concerning increased Postclassic market activity and improved obsidian access, comparison of the Late Classic and Postclassic periods is particularly important. By inspection of Figure 4c and Tables 2, 3, ratios of rims to total sherds seem to be lower for the nine Late Classic cases than for the nine Postclassic cases, likely reflecting growing use of comales in more Postclassic assemblages (possibly among other factors). A Mann-Whitney $\mathrm{U}$ test indicates that the Postclassic values are significantly higher compared to Late Classic values $(U=18, p=.026$, one tailed, for Late Classic assemblages 45, 46, 47, 49, 50, 51, 52, 54, 55 and Postclassic assemblages 58, 59, 60, 61, 62, 63, 64, 66, and 67) (Hollander and Wolfe 1973: 67-78; Siegel 1956:116-127). Consequently, the pottery tool kit is likely masking either steady obsidian access or increased access rather than an apparent decline in obsidian access during the Postclassic period, as seen in Figure 3.

With the modest number of assemblages (minus outliers) for the ratio of rims to sherds for the Late Classic and Postclassic periods, it is problematic to evaluate the degree to which the higher Postclassic rim-to-sherd ratios distort obsidian access in comparison to earlier periods. As a partial evaluation, we compare the medians of the nine Late Classic assemblages with the nine Postclassic assemblages that were used in the Mann-Whitney $\mathrm{U}$ test. Table 5 shows that the median rim-to-sherd ratio in the Postclassic period is $69 \%$ higher than the Late Classic median, while, in contrast, the median ratio of obsidian count to rim count declines by $61 \%$ and the median ratio of obsidian weight to rim count declines by $44 \%$. Therefore, for this set of Postclassic assemblages, the ratios for obsidian count and weight to ceramics decline markedly while the rim-to-sherd ratio increases markedly. This contrast suggests an increase in obsidian access because the rim to sherd ratio increases more than the other two ratios decrease; minimally, it indicates that access did not decline. Postclassic obsidian access 
compared to earlier times is masked by change in the pottery tool kit due to the wider use of comales and perhaps increased use of bowls as well.

\section{Conclusions}

We have presented a case for economic growth in obsidian production and consumption affecting the coastal lowlands, first during a technological shift to mainly pressure blade technology for obsidian household tools. A second shift during the Postclassic is more challenging to analyze. The apparent lack of improvement in obsidian access as shown on graphs of ratios of obsidian to ceramics is misleading unless the pottery tool kit (our per capita proxy) is assessed. The ratio of rims to all sherds increases, likely reflecting increased use of comales and an enlarged pottery tool kit. When this effect is taken into account, Postclassic obsidian access either held steady or, more likely, improved. If verified by additional studies, improvement in obsidian access during the Postclassic period constitutes a second instance of economic growth benefiting Mesoamerican consumers generally. For any Postclassic improvement, a likely factor was the growth of the Mesoamerican market system because some of the assemblages we analyzed predated the Aztec empire and others were not from areas administered by the Aztecs or were incorporated very late. Any dividend from "pax Azteca" was modest, although the brevity of the empire and its history suggests that "pax" was not yet in hand.

Other technological improvements than the transition to predominantly prismatic blade technology may be involved in other ways. The knapping and export of polyhedral cores for blademaking and the growing use of ground platforms are two possibilities. The degree of consistency in improved access to blades starting with the Classic period may be related to the shift to exportation of preformed polyhedral cores to coastal locations where knappers produced blades locally, largely supplanting blade importation from the highlands. In respect to platform grinding, several of our Postclassic assemblages display $80-90 \%$ ground platforms, showing that products of this technology entered inter-regional exchanges, but not all sites or geological sources are characterized by platform grinding.

Our analysis suggests that both technological change and the growth of a market system played roles in the probable Postclassic improvement in obsidian tool access. We focused on commoner consumption, but elites contributed to the process if they boosted exchange relationships for local centers. We do not wish to underplay the complexity of the processes that contributed to change in obsidian consumption. 
The analysis of long-term change in coastal lowland obsidian consumption is particularly pivotal because long-distance exchanges are at stake, linked to inter-regional relationships, not just local economies. Regional economic changes might benefit or detract from household welfare without reflecting the overall Mesoamerican situation. Our results are congruent with other Mesoamerican studies that suggest economic growth, especially by the Postclassic period, including studies in the Maya lowlands indicating growing obsidian consumption despite the availability of chert. Nevertheless, multiple economic sectors in Mesoamerica, linked to different lines of evidence, can be expected to display varied timing of changes across different regions, so a great deal remains to be examined in longterm change.

We have shown that the causes of variability in residential assemblages are diverse and will require future investigation. Bowl proportions are not available from most projects, for example, but we were able to show that unusually high bowl inventories have noteworthy effects in the case of three outliers, as does low trituration. We noted that standardization of pottery by volume may clarify whether the very early ceramic tool kit was less abundant than later, compounding the effects of bipolar and percussion flake technology on the ratios of obsidian to pottery.

Variability among household remains, sites, and regions in obsidian access is sufficient to warrant future analysis with a larger dataset to examine regional variation and assemblages from centers versus those in rural or politically marginalized contexts. Our informal scrutiny of assemblages grouped by regions (not pursued here) suggests contrasts in access, which we suspect will prove to be related to distance to obsidian sources. We suspect that flakes in most Classic and Postclassic assemblages were present as a result of further processing of materials related to the prismatic industry (by percussion or bipolar) or to occasional bifacial or core rejuvenation knapping, but this evaluation requires detailed lithic studies not yet available for all of the assemblages. At stake is whether flakes were used because of unsatisfied demand for blades. Not all regions and sites were necessarily well supplied with blades even during the Postclassic period. In future, researchers will have to make a strenuous effort to better sample "ordinary" households to establish a larger dataset for each period and representation of multiple periods to track regional patterns.

One of the encouraging implications of our investigation is that additional measures of household well-being can be investigated systematically to complement obsidian data. Other possible measures of household consumption can be envisioned, such as access to highly decorated vessels, to functionally superior vessels (e.g., more resistant to thermal stress), or special-function items 
(ornamental, ritual). Special-function items pose a greater hurdle in sample size than even obsidian, but judicious pooling of categories can improve the sample sizes. Importantly, our effort has shown that archaeologists, some of whom have not met in person, can cooperate in addressing major issues about economic and social change at an interregional scale by creating and analyzing reasonably large joint databases.

At the outset we noted both the challenges and possibilities of archaeological analyses of economic growth. Mesoamerica was never entirely subsumed in a single empire and developed diversified economies including long-distance exchanges, eventually with a multi-regional market system. Technological changes and transfers altered consumer welfare in many regions. Among the factors of interest for monitoring economic growth, several warrant consideration in Mesoamerica in addition to household welfare emphasized in our study. Noteworthy are: episodes of greater urbanization (see note 2), population growth, increased craft specialization, periods with durable states/empires, elaboration of intensive agricultural techniques, such as raised fields, and the multiple incentives of a periodic market system for a cross-section of populations. Against the backdrop of the growth and demise of polities in Mesoamerica, some of these changes may represent new advantages for populations. We traced only one thread of evidence, obsidian access in the coastal lowlands, but we stress the potential of other lines of evidence in household material culture, foodways, and health. As in the case of continuing investigations of economic growth for societies like ancient Rome, Mesoamericanists can contribute to this complex topic and its comparative potential.

\section{Acknowledgments}

In authorship, after the first author, who organized and drafted the study, authors are alphabetized. The authors acknowledge funding support in their investigations by the Colorado Archaeological Society, Consejo Nacional de Ciencia y Tecnología (CONACyT), the National Endowment for the Humanities, the National Geographic Society, the National Science Foundation, Sigma Xi, University of Colorado Graduate School, University of Colorado Dept. of Anthropology, and the Wenner Gren Foundation for Anthropological Research. All field investigations were conducted with permission from the Mexican Consejo de Arqueología of the Instituto Nacional de Antropología e Historia. In addition to our own projects, we drew upon data from publications by Chantal Esquivias and Carl Wendt. We appreciate the encouragement of a number of additional colleagues who were ultimately unable to contribute data. We thank John Clark, José Lobo, Michael Smith, Dennis Young, and two anonymous reviewers for useful suggestions, but they are not responsible for the statements in the 
paper. Stark presented a pilot study concerning coastal obsidian consumption at the $78^{\text {th }}$ annual meeting of the Society for American Archaeology in 2013.

\section{Notes}

1. In an earlier, related argument, imported obsidian prismatic blades were proposed by Clark (1987) as initially restricted to elites in places distant from producing regions but becoming widespread later. Early social restrictions on prismatic blades are not supported at one key early Gulf lowland center, San Lorenzo (De Leon 2008). Imported prismatic blades were initially scarce in many areas and may have sometimes been associated more with elites but this association is inconsistent (Hirth et al. 2013:2796; Jackson and Love 1991:52-53; Parry 1987:25, 70, 134; Stark 2007:56). Early distant centers and their high-ranking personnel undoubtedly contributed to the expansion of exchange networks overall, but at Olmec San Lorenzo, variation in source materials suggests residential diversity in obsidian networks, not centralized control (Hirth et al. 2013). Blade use expanded along with the exchange system that distributed the products from highland locations. In the Early Formative Basin of Mexico, production and trade of obsidian blades became community specializations (Boksenbaum et al. 1987:7172; Tolstoy et al. 1977:102). In various periods, blade access seems to vary according to site hierarchies and show contrasts between larger and smaller centers or between centers and rural populations (Aoyama 2001:351-355; Bove 1989; Clark 1988:45; Clark and Lee 1984:251; Santley 1989:143; 2007:164165; Sheets 2000:219-220). Social differentials in obsidian blade access remain a complicated subject, but the continuation of differentials into at least the Classic period suggests a degree of unsatisfied demand.

2. Mesoamerican cities may be associated with enhanced social capital through schools and through communications in pageantry, ritual events, and during marketplace exchanges, but some of these events also contributed to state authority and, in any case, may not have had cumulative benefits that we can link to economic growth. Mesoamerican cities are difficult to associate with many technological innovations that expanded into wider use (as opposed to social innovations), but this is too extensive a topic to discuss here (see e.g., Bettencourt 2013 concerning scaling of urban socioeconomic processes in modern settings). Ortman et al. (2015) examined settlement population versus volume of monumental construction and residential mound size (the two products) during the Basin of Mexico sequence to argue that greater settlement size and population contributed to greater productivity. This intriguing analysis is vulnerable to distortions from sequential constructions and 
cumulative occupations that may not have registered well in surface observations, but it calls attention to the possible effects of urbanization on productivity.

3. Two prismatic blades were recovered from the Late Archaic Tlacuachero shellmound on the Pacific coast of Chiapas, but they might be intrusive (Paris 2015:130).

4. Although not featured in Mesoamerican knapped industries, basalts, andesites, and other volcanic stones available in the highlands could have produced flakes and bifaces, as was characteristic in the Hohokam area in the US Southwest (Haury 1976:293-296). As a precaution, we monitor other knapped industries than chert and obsidian, but such products were not commonly circulated in Mesoamerica and do not characterize the coastal assemblages (Table 2).

5. Along the Pacific coast, some of the settlement systems from which we draw samples included seasonal and/or special-purpose sites that, during the Initial and Early Formative periods, served as locales for both salt production and more generalized resource extraction (Lesure 2009); during the Late to Terminal Formative some coastal sites were specialized in salt production (Nance 1992). At such sites, vessel form proportions are radically different from those of nearby, contemporaneous residential sites, and at times the incidence of obsidian is far lower. We have excluded such special-purpose sites from our sample. Early seasonal riverine sites for obtaining aquatic resources in the San Lorenzo area, Veracruz, also are not included in our dataset (Arnold 2009; Cyphers et al. 2013:73-90). More difficult to control is interregional variability in the commitment to sedentism during the Initial and Early Formative periods, such as discussed for La Joya in the Tuxtla Mountains (Arnold 1999; Rosenswig 2006), but sites argued to be temporary are not included in our sample.

6. During the Initial Formative period, Pacific coastal sites such as Paso de la Amada and Cuauhtémoc (1900-1300 BC) witnessed a gradual shift from (probably) boiling with heated rocks to cooking in rounded-bottom pots over direct heat (re fire cracked rocks, see Clark and Gosser 1995:215; Lesure 2010; Rosenswig 2010: 154). As a result, the summed rim proportions of cooking pots per cubic meter increased while bowls remained stable (Lesure, unpublished results). Increased cooking vessels relative to bowls would be expected to decrease ratios of obsidian to total sherds for Paso de la Amada assemblages, but any effect appears small at that site.

7. De Leon (2008) presents additional examples of residential ratios of obsidian count to total sherds for the Olmec center of San Lorenzo. With one exception, the ratios pertain to elite areas. The outlying non-elite location of Sergion Salmon yielded ratios of .04 (Early Formative San Lorenzo B phase) 
and .03 (Middle Formative Nacaste phase). These values are intermediate between EF-MF.19 San Carlos and MF.20 Tres Zapotes A and B in our data set. Several but not all elite ratios are higher at San Lorenzo, and De Leon stresses that variability among residential locations is not directly correlated with status but relates to household activities. We do not include the Sergion Salomon case because San Lorenzo excavation information is being readied for publication, and we lack the requisite details. Among the datasets we use, several are phase composites for which the individual residential locations or strata show variability, but our pooling of information moderates such variation. Our discussion of outliers supports our general expectation of some variability in obsidian consumption at the residential level, consistent with De Leon's observations.

\section{References}

Aoyama, K. 1995. Microwear analysis in the southeast Maya lowlands: two case studies at Copan, Honduras. Latin American Antiquity 6:129-144.

Aoyama, K. 1999. Ancient Maya State, Urbanism, Exchange, and Craft Specialization: Chipped Stone Evidence from the Copán Valley and the La Entrada Region, Honduras = Estado, urbanismo, intercambio, y especialización artesanal entre los mayas antiguos : evidencia de lítica menor del Valle de Copán y la región de La Entrada, Honduras. University of Pittsburgh Memoires in Latin American Archaeology No. 12. University of Pittsburgh, Dept. of Anthropology, Pittsburgh, PA.

Aoyama, K. 2001. Classic Maya state, urbanism, and exchange: chipped stone evidence of the Copán Valley and its hinterland. American Anthropologist 103:346-360.

Arnold III, P. J. 1999. Tecomates, residential mobility, and Early Formative occupation in coastal lowland Mesoamerica. In: Skibo, J. M., Feinman, G. M. (Eds.), Pottery and People. University of Utah Press, Salt Lake City, pp. 157-170.

Arnold III, P. J. 2009. Settlement and subsistence among the Early Formative Gulf Olmec. Journal of Anthropological Archaeology 28, 397-411.

Asea, P. K., Corden, W. M. 1994. The Balassa-Samuelson model: an overview. Review of International Economics 2, 191-200. 
Ball, J. W. 1983. Teotihuacan, the Maya, and ceramic interchange: a contextual perspective. In: Miller, A. G. (Ed.), Highland-Lowland Interaction in Mesoamerica: Interdisciplinary Approaches. Dumbarton Oaks Research Library and Collection, Washington, D.C., pp. 125-145.

Barrett, T. P. 2003. Tuxtlas Obsidian: Organization and Change in a Regional Craft Industry. Ph.D.

Dissertation, Dept. of Anthropology, University of New Mexico, Albuquerque, New Mexico.

Baumard, N., Hyafil, A., Morris, I., Boyer, P. 2015. Increased affluence explains the emergence of ascetic wisdoms and moralizing religions. Current Biology 25(1):10-15.

Berdan, F. F., Masson, M. A., Gasco, J., Smith M. E. 2003. An International economy. In: Smith, M. E., Berdan, F. F. (Eds.), The Postclassic Mesoamerican World. The University of Utah Press, Salt Lake City, pp. 96-108.

Bettencourt, Luis M. A. 2013. The origins of scaling in cities. Science 340:1438-1441.

Blanchard, O. J., Fischer, S. 1989. Lectures on Macroeconomics. Cambridge, Mass.: MIT Press.

Blanton, R. E. 1983. Factors underlying the origin and evolution of market systems. In: Ortiz, S. (Ed.), Economic Anthropology: Topics and Theories Monographs in Economic Anthropology, No. 1. University Press of America, Lanham. MD, pp. 51-66.

Blanton, R. E. 1985. A comparison of early market systems. In: Plattner, S. (Ed.), Markets and Marketing. University Press of America, Lanham, MD, pp. 399-416.

Blanton, R. E. 1994. Houses and Households: a Comparative Study. Plenum Press, New York.

Blanton, R. E. 1996. The Basin of Mexico market system and the growth of empire. In: Berdan, F. F., Blanton, R. E., Boone, E. H., Hodge, M. G., Smith, M. E., Umberger, E. (Eds.), Aztec Imperial Strategies. Dumbarton Oaks Research Library and Collection, Washington, D.C. ,pp. 47-84. 
Blanton, R. E., Fargher, L. F., Heredia Espinoza, V. Y. 2005. The Mesoamerican world of goods and its transformations. In: Blanton, R. E., (Ed.), Settlement, Subsistence, and Social Complexity: Essays Honoring the Legacy of Jeffrey R. Parsons. Cotsen Institute of Archaeology, University of California, Los Angeles, CA., pp. 260-294.

Blanton, R. E., Kowalewski, S. A., Feinman, G. M., Finsten, L. M. 1993. Ancient Mesoamerica: a Comparison of Change in Three Regions, 2nd ed. Cambridge University Press, New York, NY.

Boksenbaum, M. W. 1980. Basic Mesoamerican stone-working: nodule smashing? Lithic Technology 9:12-26.

Boksenbaum, M. W., Tolstoy, P., Harbottle, G., Kimberlin, J., Nievens M. 1987. Obsidian industries and cultural evolution in the Basin of Mexico before 500 B.C. Journal of Field Archaeology 14:65-76.

Boskin, M. J., Dulberger, E. R,. Gordon, R. J., Griliches, Z., Jorgenson, D. W. 1998. Consumer prices, the consumer price index, and the cost of living. The Journal of Economic Perspectives 12:3-26.

Bove, F. J. 1989. Chiefdoms/states in Escuintla, Guatemala: the obsidian evidence. In: Gaxiola González, M., Clark, J. E. (Eds.), La Obsidiana en Mesoamérica. Colección Científica 176, Instituto Nacional de Antropología e Historia, Mexico, D.F., pp. 401-418.

Boxt, M. A., Raab, L. M., González Lauck, R. B. 2012. Isla Alor: Olmec to contact in the La Venta hinterland. In: Boxt, M. A., Dillon, B. D. (Eds.), Fanning the Sacred Flame: Mesoamerican Studies in Honor of H. B. Nicholson. University of Colorado Press, Boulder, pp. 55-92.

Braswell, G. E. 2003. Obsidian exchange spheres. In: M. E. Smith, M. E., Berdan, F. F. (Eds.), The Postclassic Mesoamerican World. University of Utah Press, Salt Lake City, pp. 131-158.

Brodbeck, M. 1993. The Role of Domestic Prismatic Blade Use in the Social Development of La Mixtequilla, Veracruz, Mexico. M.A. thesis, Dept. of Anthropology, Arizona State University, Tempe. 
Buck, B. A. 1982. Ancient technology in contemporary surgery. Western Journal of Medicine 136:265269.

Carballo, D. M. 2013. The social organization of craft production and interregional exchange at Teotihuacan. In: Hirth, K. G., Pillsbury, J. (Eds.), Merchants, Markets, and Exchange in the PreColumbian World. Dumbarton Oaks Research Library and Collection, Washington, D.C., pp. 113-140.

Childe, V. G. 1951 [1936] revised edition. Man Makes Himself. New York: New American Library.

Clark, J. E. 1981. The Early Preclassic obsidian industry of Paso de la Amada, Chiapas, Mexico. Estudiios de Cultura Maya 13:265-284.

Clark, J. E. 1987. Politics, prismatic blades and Mesoamerican civilization. In: Johnson, J. K., Morrow, C. A. (Eds.), The Organization of Core Technology, Westview Press, Boulder, CA., pp. 259-284.

Clark, J. E. 1989. Obsidian tool manufacture. In: Voorhies, B. (Ed.), Ancient Trade and Tribute: Economies of the Soconusco Region of Mesoamerica. University of Utah Press, Salt Lake City, pp. 215228.

Clark, J. E. 2003. A review of twentieth-century Mesoamerican obsidian studies. In: Hirth, K. G. (Ed.), Mesoamerican Lithic Technology: Experimentation and Interpretation. University of Utah Press, Salt Lake City, pp. 15-54.

Clark, J. E., Bryant, D. D. 1997. A technological typology of prismatic blades and debitage from Ojo de Agua, Chiapas, Mexico. Ancient Mesoamerica 8:111-136.

Clark, J. E., Gosser, D. 1995. Reinventing Mesoamerica's first pottery. In: Barnett, W. K., Hoopes, J. W. (Eds.), The Emergence of Pottery. Smithsonian Institution Press, Washington, D.C., . pp. 209-222.

Clark, J. E., Lee, Jr., T. A. 1984. Formative obsidian exchange and the emergence of public economies in Chiapas, Mexico. In: Hirth, K. J. (Ed.), Trade and Exchange in Early Mesoamerica. University of New Mexico Press, Albuquerque, pp. 235-274. 
Clark, J. E., Lee, Jr., T. A., Salcedo, T. 1989. The distribution of obsidian. In: Voorhies, B. (Ed.), Ancient Trade and Tribute: Economies of the Soconusco Region of Mesoamerica, University of Utah Press, Salt Lake City, pp. 268-284.

Cowgill, G. L. 2015. Ancient Teotihuacan: Early Urbanism in Central Mexico. Cambridge University Press, N.Y.

Cyphers, A., Zurita Noguera, J., Lane Rodríguez, M. 2013. Retos y Riesgos en la Vida Olmeca. Instituto de Investigaciones Antropológicas, Universidad Nacional Autónoma de México, Mexico, D.F.

Darras, V. 2008. Estrategias para la producción de navajas de obsidiana en la región de Zacapu y la vertienete del Lerma (Michoacan, México) entre el Epiclásico y el Posclásico Tardío. Ancient Mesoamerica 19:243-264.

De Leon, J. P. 2008. The Lithic Industries of San Lorenzo-Tenochtitlan: An Economic and Technological Study of Olmec Obsidian. Ph.D. Dissertation, Dept. of Anthropology, Pennsylvania State University.

De Leon, J. P., Hirth K. G., Carballo D. M. 2009. Exploring Formative Period obsidian blade trade: three distribution models. Ancient Mesoamerica 20:113-128.

Earle, T., Smith, M. E. 2012. Household economies under the Aztec and Inka empires. In: Smith, M.E. (Ed.), The Comparative Archaeology of Complex Societies. Cambridge University Press, Cambridge, England, pp. 238-284.

Erreygers, G. 2009. Hotelling, Rawls, Solow: how exhaustible resources came to be integrated into the neoclassical Growth model. In: Boianovsky, M., Hoover, K. D. (Eds.), Robert Solow and the Development of Growth Economics. Duke University Press, Durham, NC, pp. 263-281.

Esquivias, C. 2003. On the edge of empire? Settlement changes in Chacalapan, southern Veracruz, Mexico, during the Classic and Postclassic periods. Ph.D. dissertation, Dept. of Archaeology, Boston University. 
Feinman, G. M., Nicholas, L. M. 2000. High-intensity household-scale production in ancient Mesoamerica: a perspective from Ejiutla, Oaxaca. In: Feinman, G. M., Manzanilla, L. (Eds.), Cultural Evolution: Contemporary Viewpoints, Kluwer Academic/Plenum Publishers, New York, pp. 119-142.

Feinman, G. M., Nicholas, L. M. 2010. A multiscalar perspective on market exchange in the Classic-Period Valley of Oaxaca. In: Garraty, C. P., Stark, B. L. (Eds.), Archaeological Approaches to Market Exchange in Ancient Societies, University Press of Colorado, Boulder, CO, pp. 85-98.

Gasco, J. 2015. Investigaciones arqueológicas recientes en Gonzalo Hernández, un sitio del Posclásico Tardío en el Soconusco. EntreDiversidades, Primavera-verano 2015, pp. 13-33. Universidad Autónoma de Chiapas.

Golitko, M., Feinman, G. M. 2015. Procurement and distribution of pre-Hispanic Mesoamerican obsidian 900 BC-AD 1520: a social network analysis. Journal of Archaeological Method and Theory 22:206-247.

Grief, A. 2005. Comment on Hitchner and Saller. In: Manning, J.G., Morris, I., The Ancient Economy: Evidence and Models. Stanford University Press, Stanford, CA, pp. 239-242.

Hahn, F.H., Matthews, R. C. O. 1964. The theory of economic growth: a survey. Economic Journal 74:825-832.

Haury, E. W. 1976. The Hohokam: Desert Farmers and Craftsmen. The University of Arizona Press, Tucson.

Healan, D. M. 2009. Ground platform preparation and the "banalization" of the prismatic blade in western Mesoamerica. Ancient Mesoamerica 20:103-111.

Hedgepeth, J. D. 2009. The Domestic Economy of Early Postclassic Rio Viejo, Oaxaca, Mexico: Daily Practices and Worldviews of a Commoner Community. Unpublished M.A. Thesis, Department of Anthropology, University of Colorado. 
Hedgepeth, J. D. 2010. The Domestic Economy of Early Postclassic Río Viejo, Oaxaca: Daily Practice in the Wake of Administrative Collapse. VDM Verlag Dr. Müller Aktiengesellschaft \& Co., Saarbruecken, Germany.

Heller, L. 1986. An Analysis of the Bipolar and Prismatic Blade Industries at El Balsamo, Guatemala. Unpublished Master's Paper, Dept. of Anthropology, Arizona State University, Tempe.

Heller, L. 2000. Postclassic obsidian workshop debris from El Sauce, Veracruz, Mexico. Mexicon 22:139146.

Heller, L., Stark, B. L. 1989. Economic organization and social context of a Preclassic center on the Pacific Coast of Guatemala: El Balsamo, Escuintla. In: Bove, F., Heller, L. (Eds.), New Frontiers in the Archaeology of the Pacific Coast of Southern Mesoamerica. Anthropological Research Papers. vol. 39. Arizona State University, Tempe, AZ, pp. 43-64.

Hepp, G. D. 2015. La Consentida: Initial Early Formative Period Settlement, Subsistence, and Social Organization on the Pacific Coast of Oaxaca, Mexico. Ph.D. dissertation, Dept. of Anthropology, University of Colorado, Boulder, CO.

Hirth, K. G., Castanzo, R. 2006. Production for use or exchange: obsidian consumption at the workshop, household, and regional levels. In: Hirth, K. G. (Ed.), Obsidian Craft Production in Ancient Central Mexico: Archaeological Research at Xochicalco. The University of Utah Press, Salt Lake City, UT., pp. 218-240.

Hirth, K., Cyphers, A., Cobean, R., De León, J., Glascock, M. D. 2013. Early Olmec obsidian trade and economic organization at San Lorenzo. Journal of Archaeological Science 40:2784-2798.

Hitchner, R. B. 2005. "The advantages of wealth and luxury": the case for economic growth in the Roman empire. In: Manning, J. G., Morris, I. (Eds.), The Ancient Economy: Evidence and Models. Stanford University Press, Stanford, CA., pp. 207-222. 
Hollander, M., Wolfe, D. A. 1973. Nonparametric Statistical Methods. Wiley, New York.

Hopkins, K. 1983. Introduction. In: Garnsey, P., Hopkins, K., Whittaker, C.R. (Eds.), Trade in the Ancient Economy. University of California Press, Berkeley, CA., pp. ix-xxv.

Hosler, D. 1994. The sounds and colors of power : the sacred metallurgical technology of ancient West Mexico. MIT Press, Cambridge, Mass.

Hosler, D. 2003. Metal production. In: Smith, M.E., Berdan, F. F. (Eds.), The Mesoamerican Postclassic World. The University of Utah Press, Salt Lake City, pp. 159-171.

Jackson, T. L., Love, M. W. 1991. Blade running: obsidian production and the introduction of prismatic blades at La Blanca, Guatemala. Ancient Mesoamerica 2:47-59.

Jones, C. I., Romer, P. M. 2010. The New Kaldor facts: ideas, institutions, population, and human capital. American Economic Journal: Macroeconomics 2010 2(1):224-245.

Jongman, W. M. 2014. Reconstructing the Roman economy. In: Neal, L., Williamson, J. G., Wilson, A. (Eds.), The Cambridge History of Capitalism. Cambridge University Press, New York, pp. 75-100.

Joyce, A. A. 1991. Formative Period Occupation in the Lower Río Verde Valley, Oaxaca, Mexico: Interregional Interaction and Social Change. Ph.D. dissertation, Department of Anthropology, Rutgers University. University Microfilms, Ann Arbor, Michigan.

Joyce, A. A., Elam, J. M., Glascock, M. D., Neff, H., Winter, M. 1995. Exchange implications of obsidian source analysis from the Lower Río Verde Valley, Oaxaca, Mexico. Latin American Antiquity 6:3-15.

Joyce, A. A., Winter, M., Mueller, R. G. 1998. Arqueología de la costa de Oaxaca: Asentamientos del periodo formativo en el valle del Río Verde inferior. Estudios de Antropología e Historia No. 40. Centro INAH Oaxaca, Oaxaca, Mexico.

Joyce, A. A., Bustamante, L. A., Levine, M. N. 2001. Commoner power: a case study from the Classic Period collapse on the Oaxaca coast. Journal of Archaeological Method and Theory 8:343-385. 
Joyce, A. A., Levine, M. N., King, S. M., Hedgepeth Balkin, J., Barber, S. B. 2014. Political transformations and the everyday in Postclassic Oaxaca. Ancient Mesoamerica 25:389 - 410.

Kaldor, N., and J. A. Mirrlees, J. A. 1961-1962. A new model of economic growth. Review of Economic Studies 29:174-190.

Kepecs, S. 2003. Salt sources and production. In: Smith, M. E., Berdan, F. F. (Eds.), The Postclassic Mesoamerican World. The University of Utah Press, Salt Lake City, pp. 126-130.

King, S. M. 2003. Social Practices and Social Organization in Ancient Coastal Oaxacan Households. Ph.D. dissertation, Dept. of Anthropology, University of California, Berkeley.

King, S. M. 2008. Interregional networks of the Oaxacan Early Postclassic: connectiing the coast and the highlands. In: Blomster, J. P. (Ed.), After Monte Albán: Transformation and Negotiation in Oaxaca, Mexico. University of Colorado Press, Boulder, CO, pp. 255-291.

Knight, C. 2003. Obsidian production, consumption, and distribution at Tres Zapotes: piecing together political economy. In: Pool, C. A. (Ed.), Settlement Archaeology and Political Economy at Tres Zapotes, Veracruz, Mexico. Monograph 50, Cotsen Institute of Archaeology University of California Los Angeles, Los Angeles, pp. 69-89.

Knight, C. L. F. Glascock, M. D. 2009. The Terminal Formative to Classic Period obsidian assemblage at Palo Errado, Veracruz, Mexico. Latin American Antiquity 20:507-524.

Kohl, P. L. 1987. The use and abuse of world systems theory. In: Schiffer, M. B. (Ed.), Advances in Archaeological Method and Theory, vol. 11, Academic Press, Inc, New York , pp. 1-35.

Kremer, M. 1993. Population growth and technological change: one million B.C. to 1990. The Quarterly Journal of Economics 108:681-716.

Lee, R. D. 1988. Induced population growth and induced technological progress: their interaction in the accelerating stage. Mathematical Population Studies 1:265-288. 
Lesure, R. G. 1999. Platform architecture and activity patterns in an early Mesoamerican village in Chiapas, Mexico. Journal of Field Archaeology 26:391-406.

Lesure, R. G. 2009. Settlement and Subsistence in Early Formative Soconusco : El Varal and the Problem of inter-site Assemblage Variation. Cotsen Institute of Archaeology Press, Los Angeles.

Lesure, R. G. 2010. Settlement and Subsistence in Early Formative Soconusco: El Varal and the Problem of Inter-Site Assemblage Variation. Cotsen Institute of Archaeology Press, University of California Los Angeles.

Lesure, R. G. 2011. Paso de la Amada as a ceremonial center. In: Lesure, R. G. (Ed.), Early Mesoamerican Social Transformations: Archaic and Formative Lifeways in the Soconusco Region. University of California Press, Berkeley, pp. 119-145.

Lesure, R. G., Blake, M. 2002. Interpretive challenges in the study of early complexity: economy, ritual, and architecture at Paso de la Amada, Mexico. Journal of Anthropological Archaeology 21:1-24.

Levine, M. N. 2007. Linking Household and Polity at Late Postclassic Period Yucu Dzaa (Tututepec), a Mixtec Capital on the Coast of Oaxaca, Mexico Ph.D. Dissertation, Department of Anthropology, University of Colorado.

Levine, M. N. 2011. Negotiating political economy at Late Postclassic Tututepec (Yucu Dzaa), Oaxaca, Mexico. American Anthropologist 113:22-39.

Levine, M. N. 2014. Obsidian obsessed? Examining patterns of chipped-stone procurement at Late Postclassic Tututepec, Oaxaca. In: Levine, M. N., Carballo, D. M. (Eds.), Obsidian Reflections: Symbolic Dimensions of Obsidian in Mesoamerica. University Press of Colorado, Boulder, CO, pp. 159-191.

Levine, M. N., Carballo, D. M. (Eds.). 2014. Obsidian Reflections: Symbolic Dimensions of Obsidian in Mesoamerica. University Press of Colorado, Boulder, CO. 
Lewenstein, S. 1981. Mesoamerican obsidian blades: an experimental approach to function. Journal of Field Archaeology 8:175-188.

Lewenstein, S. 1987. Stone Tool Use at Cerros : The Ethnoarchaeological and Use-wear Evidence. University of Texas Press, Austin.

Malthus, T. R. 1997[1798]. An Essay on the Principle of Population. Elecbook, London.

Manzanilla, L. R. 2015. Cooperation and tensions in multiethnic corporate societies using Teotihuacan, Central Mexico, as a case study. PNAS, Proceedings of the National Academy of Sciences of the United States of America 112:9210-9215.

Masson, M. A., Freidel, D. A. 2012. An argument for Classic era Maya market exchange. Journal of Anthropological Archaeology 31:455-484.

Millett, P. 2001. Productive to some purpose? The problem of ancient economic growth. In: Mattingly, D.J., Salmon, J. (Eds.), Economies Beyond Agriculture in the Classical World. Routledge, London, pp. 1748.

Morris, I. 2005. Archaeology, standards of living, and Greek economic history. In: Manning, J. G., Morris. I. (Eds.), The Ancient Economy: Evidence and Models. Stanford University Press, Stanford, CA, pp 91126.

Morris, I. 2010. Why the West Rules-- for Now: the Patterns of History, and What They Reveal about the Future. 1st ed. Farrar, Straus and Giroux, New York.

Morris, I. 2013. The Measure of Civilization: How Social Development Decides the Fate of Nations. Princeton University Press, Princeton. 
Mountjoy, J. B., Taylor, R. E., Feldman, L. H. 1972. Matanchén Complex: new radiocarbon dates on early coastal adaptation in West Mexico. Science 175:1242-1243.

Nance, C. R. 1992. Guzmán mound: a Late Preclassic salt works on the south coast of Guatemala. Ancient Mesoamerica 3:27-46.

Navarro Castillo, M. 2014. Household economies: the production and consumption of plumbate at Miguel Alemán, the Conquista Campesina Complex and the Piñuela Complex. Ph.D. dissertation, Dept. of Anthropology, University at Albany -SUNY, Albany, NY.

Navarro Castillo, M. 2015. Plumbate y su consumo como marcador social en el Soconusco. Mexicon: The Journal of Mesoamerican Studies 37:91-100.

Neff, H. 2014. Informe y Solicitud de Permiso 2014, Proyecto Arqueológico Costa del Soconusco (PACS): Informe de la Temporada de Campo 2013 y Solicitud de Permiso para 2014. Presented to the Consejo de Arqueología Instituto Nacional de Antropología, Mexico, D.F. https://www.academia.edu/8240036/Proyecto Arqueologico Costa del Soconusco PACS Informe de la segunda temporada de investigaciones 2014, accessed 7 September 2015.

Nelson, Jr., F. W., Clark, J. E. 1998. Obsidian production and exchange in eastern Mesoamerica. In: Rattray, E. C. (Ed.), Rutas de Intercambio en Mesoamerica: III Coloquio Pedro Bosch Gimpera. Instituto de Investigaciones Antropológicas, Universidad Nacional Autónoma de México, Mexico, D.F., pp. 277333.

Nelson, F. W., Voorhies, B. 1980. Trace element analysis of obsidian artifacts from three shell midden sites in the littoral zone, Chiapas, Mexico. American Antiquity 45:540-550.

Nichols, D. L. 2015. Teotihuacan. Journal of Archaeological Research (only available online at present, shortly to be out in print for more detailed citation. DOI 10.1007/s10814-015-9085-0

Ortman, S. G., Cabaniss, A. H. F., Sturm, J. O., Bettencourt, L. M. A. 2015. Settlement scaling and increasing returns in an ancient society. Science Advances 1(1):1-8. 
Paris, E. H. 2015. Early use of chipped stone at Tlacuachero. In: Voorhies, B. (Ed.), An Archaic Mexican Shellmound and its Entombed Floors. UCLA Cotsen Institute of Archaeology Press, Los Angeles, pp. 127143.

Parry, W. J. 1987. Chipped Stone Tools in Formative Oaxaca, Mexico: Their Procurement, Production, and Use. University of Michigan, Museum of Anthropology, Memoir 20, Ann Arbor.

Pastrana, A., and Athie, I. 2014. The symbolism of obsidian in Postclassic Central Mexico. In: Levine, M. N., Carballo, D. M. (Eds.), Obsidian Reflections: Symbolic Dimensions of Obsidian in Mesoamerica. University Press of Colorado, Boulder, CO, pp. 75-110.

Persson, K.G. 1988. Pre-industrial Economic Growth: Social Organization, and Technological Progress in Europe. Blackwell, Oxford.

Pool, C. A., Knight, C. L. F., Glascock, M. 2014. Formative obsidian procurement at Tres Zapotes, Veracruz, Mexico: implications for Olmec and Epi-Olmec political economy. Ancient Mesoamerica 25:271-293.

Raab, L. M., Boxt, M. A., Bradford, K. 1994, Proyecto Arqueológico La Venta. Temporada 1994. Informe de las investigaciones arqueológicas en el área de apoyo de La Venta, Huimanguillo, Tabasco, México. Instituto Nacional de Antropología e Historia, Coordinación Nacional de Arqueología, Archivo Técnico, 1997.

Raab , L. M.,. Boxt, M. A., Bradford, K. 1995. Proyecto Arqueológico La Venta. Temporada 1995. Informe de las investigaciones arqueológicas en el área de apoyo de La Venta, Huimanguillo, Tabasco", México. Instituto Nacional de Antropología e Historia, Coordinación Nacional de Arqueología, Archivo Técnico, 1997.

Raab, L. M., Boxt, M. A., Bradford, K., Stokes, B. A., Gonzalez Lauck, R. B. 2000. Testing at Isla Alor in the La Venta Olmec hinterland. Journal of Field Archaeology 27(3):257-270. 
Rathje, W. L. 1972. Praise the gods and pass the metates: a hypothesis of the development of lowland rainforest civilizations in Mesoamerica. In: Leone, M. P. (Ed.), Contemporary Archaeology: A Guide to Theory and Contributions. Southern Illinois University Press, Carbondale, pp. 365-392.

Rebnegger, K. J. 2010. Obsidian production and changing consumption in the Lake Pátzcuaro Basin, Michoacán, Mexico. Ancient Mesoamerica 21:79-89.

Robles Fernández, E. 2004. Consumo de obsidiana en el sitio Olmeca RARO-154 (San Carlos, Veracruz). Tesis de licenciatura, Facultad de Antropología, Universidad Veracruzana, Xalapa, Ver.

Rogoff, K. 1996. The purchasing power parity puzzle. Journal of Economic Literature 34:647-668.

Rosenswig, R. M. 2006. Sedentism and food production in early complex societies of the Soconusco, Mexico. World Archaeology 38:329-354.

Rosenswig, R. M. 2009. Early Mesoamerican garbage: ceramic and daub discard patterns from Cuauhtémoc, Soconusco, Mexico. Journal of Archaeological Method and Theory 16:1-32.

Rosenswig, R. M. 2010. The Beginnings of Mesoamerican Civilization: Inter-regional Interaction and the Olmec. Cambridge University Press, Cambridge, England.

Rosenswig, R. M. 2012. The first 1000 years of ceramic use in the Soconusco: evidence from the Cuauhtémoc site. In: Lowe, L. S., Pye, M. E. (Eds.), Arqueología Reciente de Chiapas: Contribuciones del Encuentro Celebrado en el 60th Aniversario de la Fundación Arqueológica Nuevo Mundo. Papers of the New World Archaeological Foundation No. 72. New World Archaeological Foundation, Brigham Young University, Provo, Utah, pp. 223-235.

Rosenswig, Robert M., Rebecca Mendelsohn, Caroline Antonelli, Rosemary Lieske, and Yahaira NúñezCortés. 2014. Proyecto de Reconocimiento Regional de Izapa 2012: Informe Técnico Parcial. Report submitted to the Consejo de Arqueología, Instituto Nacional de Antropología e Historia, Mexico City. 
Saller, R. 2005. Framing the debate over growth in the ancient economy. In: Manning, J.G. , Morris, I. (Eds.), The Ancient Economy: Evidence and Models. Stanford, CA: Stanford University Press, pp. 223238.

Sanders, W. T., Price, B. J. 1968. Mesoamerica: The Evolution of a Civilization. Random House, New York.

Sanders, W. T., Santley, R. S. 1983. A tale of three cities: energetics and urbanization in pre-Hispanic Central Mexico. In: Vogt, E. Z., Leventhal, R. M. (Eds.), Prehistoric Settlement Patterns: Essays in Honor of Gordon R. Willey. University of New Mexico Press and Peabody Museum of Archaeology and Ethnology, Harvard University, Cambridge, Mass, pp. 243-291.

Sandilands, R. J. 2009. Solovian and new growth theory from the perspective of Allyn Young on macroeconomic increasing returns. In: Boianovsky, M., Hoover, K. D. (Eds.), Robert Solow and the Development of Growth Economics. Annual Supplement to volume 41, History of Political Economy. Duke University Press, Durham, NC, pp, 285-303.

Santley, R. S. 1983. Obsidian trade and Teotihuacan influence in Mesoamerica. In: Miller, A. G. (Ed.), Highland-Lowland Interaction in Mesoamerica: Interdisciplinary Approaches. Dumbarton Oaks Research Library and Collection, Washington, D.C., pp. 69-124.

Santley, R. S. 1984. Obsidian exchange, economic stratification, and the evolution of complex society in the Basin of Mexico. In: Hirth, K. (Ed.), Trade and Exchange in Early Mesoamerica. University of New Mexico Press, Albuquerque, pp. 69-124.

Santley, R. S. 1989. Obsidian working, long distance exchange, and the Teotihuacan presence on the south Gulf coast. In: Diehl, R. A., Berlow, J. C. (Eds.), Mesoamerica after the Decline of Teotihuacan A.D. 700-900. Dumbarton Oaks, Washington D.C., pp. 131-151.

Santley, R. S. 2007. The Prehistory of the Tuxtlas. University of New Mexico Press, Albuquerque.

Scheidel, W. 2010. Real wages in early economies: evidence for living standards from 1800 BCE to 1300 CE. Journal of the Economic \& Social History of the Orient 53:425-462. 
Scheidel, W. Friesen, S. J. 2009. The size of the economy and the distribution of income in the Roman empire. The Journal of Roman Studies 99:61-91.

Sen, A. 1970. Introduction. In: Sen, A. (Ed.), Growth Economics: Selected Readings. Harmondsworth, Middlesex, England: Penguin Books, Inc., pp. 9-40.

Shafer, H. J., Hester, T. R. 1991. Lithic craft specialization and product distribution at the Maya site of Colha, Belize. World Archaeology 23:79-97.

Sharer, R. J. 1983. Interdisciplinary approaches to the study of Mesoamerican highland-lowland interaction: a summary view. In: Miller, A. G. (Ed.), Highland-Lowland Interaction in Mesoamerica: Interdisciplinary Approaches. Dumbarton Oaks Research Library and Collection, Washington, D.C., pp. 241-263.

Sheets, P. 2000. Provisioning the Ceren household: the vertical economy, village economy, and household economy in the southeastern Maya periphery. Ancient Mesoamerica 11:217-230.

Sheets, P.D., Muto, G. R. 1972. Pressure blades and total cutting edge: an experiment in lithic technology. Science 175:632-634.

Sidrys, R. 1977. Mass-distance measures for the Maya obsidian trade. In: Earle, T. K., Ericson, J. E. (Eds.), Exchange Systems in Prehistory. Academic Press, New York, pp. 91-107.

Siegel, S. 1956. Nonparametric Statistics for the Behavioral Sciences. McGraw-Hill, New York.

Smith, M. E. 1987. Household possessions and wealth in agrarian states: Implications for archaeology. Journal of Anthropological Archaeology 6:297-335.

Smith, M. E. 2003. Key commodities. In: Smith, M. E., Berdan, F. F. (Eds.), The Postclassic Mesoamerican World. University of Utah Press, Salt Lake City, pp. 117-125. 
Snowdon, B. 2009. The Solow model, poverty traps, and the foreign aid debate. In: Boianovsky, M., Hoover, K. D. (Eds.), Robert Solow and the Development of Growth Economics. Annual Supplement to Volume 41, History of Political Economy. Duke University Press, Durham, NC., pp. 241-262.

Solow, R. M. 1956. A contribution to the theory of economic growth. Quarterly Journal of Economics 70:65-94.

Solow, R. M. 1957. Technical change and the aggregate production function. Review of Economics and Statistics 39:312-320.

Spielmann, K. A. 1986. Interdependence among egalitarian societies. Journal of Anthropological Archaeology 5:279-312.

Stark, B. L. 1977. Prehistoric Ecology at Patarata 52, Veracruz, Mexico: Adaptation to the Mangrove Swamp. Vanderbilt University Publications in Anthropology no. 18, Vanderbilt University, Nashville.

Stark, B. L. 1984. Pottery in relation to economy and social organization at El Balsamo, Escuintla, Guatemala. In: XVII Mesa Redonda, Investigaciones Recientes en el Área Maya, vol. 2. Sociedad Mexicana de Antropología, San Cristobal de las Casas, Chiapas, Mexico, pp. 293-309.

Stark, B. L. 1989. Patarata Pottery: Classic Period Ceramics of the South-Central Gulf Coast, Veracruz, Mexico. University of Arizona Press, Tucson.

Stark, B. L. 2000. Framing the Gulf Olmec. In: Clark, J. E., Pye, M. E. (Eds.), Olmec Art and Archaeology in Mesoamerica. National Gallery of Art, Washington D.C., pp. 31-53.

Stark, B. L. 2007. Out of Olmec. In: Scarborough, V.L., Clark, J.E. (Eds.), The Political Economy of Ancient Mesoamerica: Transformations during the Formative and Classic Periods. University of New Mexico Press, Albuquerque, pp. 47-63. 
Stark, B. L., (Ed.). 2001. Classic Period Mixtequilla, Veracruz, Mexico : Diachronic Inferences from Residential Investigations. Institute for Mesoamerican Studies, University at Albany, distributed by University of Texas Press, Albany, N.Y. and Austin, TX.

Stark, B. L. 2007. Diachronic Change in Crafts and Centers in South-central Veracruz, Mexico. In: Shimada, I. (Ed.), Craft Production in Complex Societies: Multi-craft and Producer Perspectives. University of Utah Press, Salt Lake City, pp. 227-261.

Stark, B. L., Alanna Ossa, A. 2010. Origins and development of Mesoamerican marketing: evidence from south-central Veracruz, Mexico. In: Garraty, C. P., Stark, B. L. (Eds.), Archaeological Approaches to Market Exchange in Ancient Societies. University of Colorado Press, Boulder, CA., pp. 99-126.

Storey, R. 1992. Life and Death in the Ancient City of Teotihuacan: a Modern Paleodemographic Synthesis. University of Alabama Press, Tuscaloosa.

Swan, T. W. 1956. Economic growth and capital accumulation. Economic Record 32:334-361.

Todaro, M. P. 1997. Economic Development. New York: Addison Wesley Longman Limited.

Tolstoy, P., Fish, S. K., Boksenbaum, M. W., Vaughn, K. B., Smith, C. E. 1977. Early sedentary communities of the Basin of Mexico. Journal of Field Archaeology 4:91-106.

Venter, M. L. 2008. Community Strategies in the Aztec Imperial Frontier: Perspectives from Totogal, Veracruz, Mexico. Ph.D. dissertation, Dept. of Anthropology, University of Kentucky.

Voorhies, B. 2004. Coastal Collectors in the Holocene : The Chantuto people of Southwest Mexico. University Press of Florida, Gainesville, FL.

Voorhies, B., Gasco, J. 2004. Postclassic Soconusco Society: The Late Prehistory of the Coast of Chiapas, Mexico. IMS monograph 14. Institute for Mesoamerican Studies, University at Albany, Albany, NY. Distributed by University of Texas Press, Austin. 
Wendt, C. J. 2003. Early Formative Domestic Organization and Community Patterning in the San Lorenzo Tenochtitlan Region, Veracruz, Mexico. Ph.D. dissertation, Dept. of Anthropology, The Pennsylvania State University.

Wendt, C. J. 2010. A San Lorenzo phase household assemblage from El Remolino, Veracruz. Ancient Mesoamerica 21:107-122.

Wilk, R. R., and Rathje, W. L. 1982. Household archaeology. American Behavioral Scientist 25:617-639.

Wilkerson, S. J. K. 1975. Pre-agricultural village life: the Late Preceramic Period in Veracruz. In Studies in Ancient Mesoamerica, II, vol. 27. Archaeological Research Facility, Department of Anthropology, Berkeley, CA. pp. 111-121.

Williams, D. T. 2012. Typological and Geochemical Analysis of Obsidian Artifacts: A Diachronic Study from the Lower Rio Verde Valley, Oaxaca, Mexico. Unpublished MA Thesis, Department of Anthropology, University of Colorado, Boulder, CO.

Workinger, A. 2002. Highland/Coastal Interaction in Prehispanic Oaxaca, Mexico: The Perspective from San Francisco de Arriba. Ph.D. dissertation, Department of Anthropology, Vanderbilt University. UMI: Ann Arbor, MI.

\section{Figure Captions}

Figure 1. Map showing locations of three highland sites mentioned and of coastal sites analyzed.

Figure 2. Obsidian count and weight to rim and sherd counts, graphed as ratios. Black boxes indicate outlier values.

Figure 3. Classic and Postclassic ratios of obsidian count and weight to rim and sherd counts. Outlier values are shown as black boxes.

Figure 4. Rim count to sherd count ratios, (a) all periods, (b) Classic and Postclassic periods, and (c) Classic and Postclassic periods with three outlier values removed. 
Figures

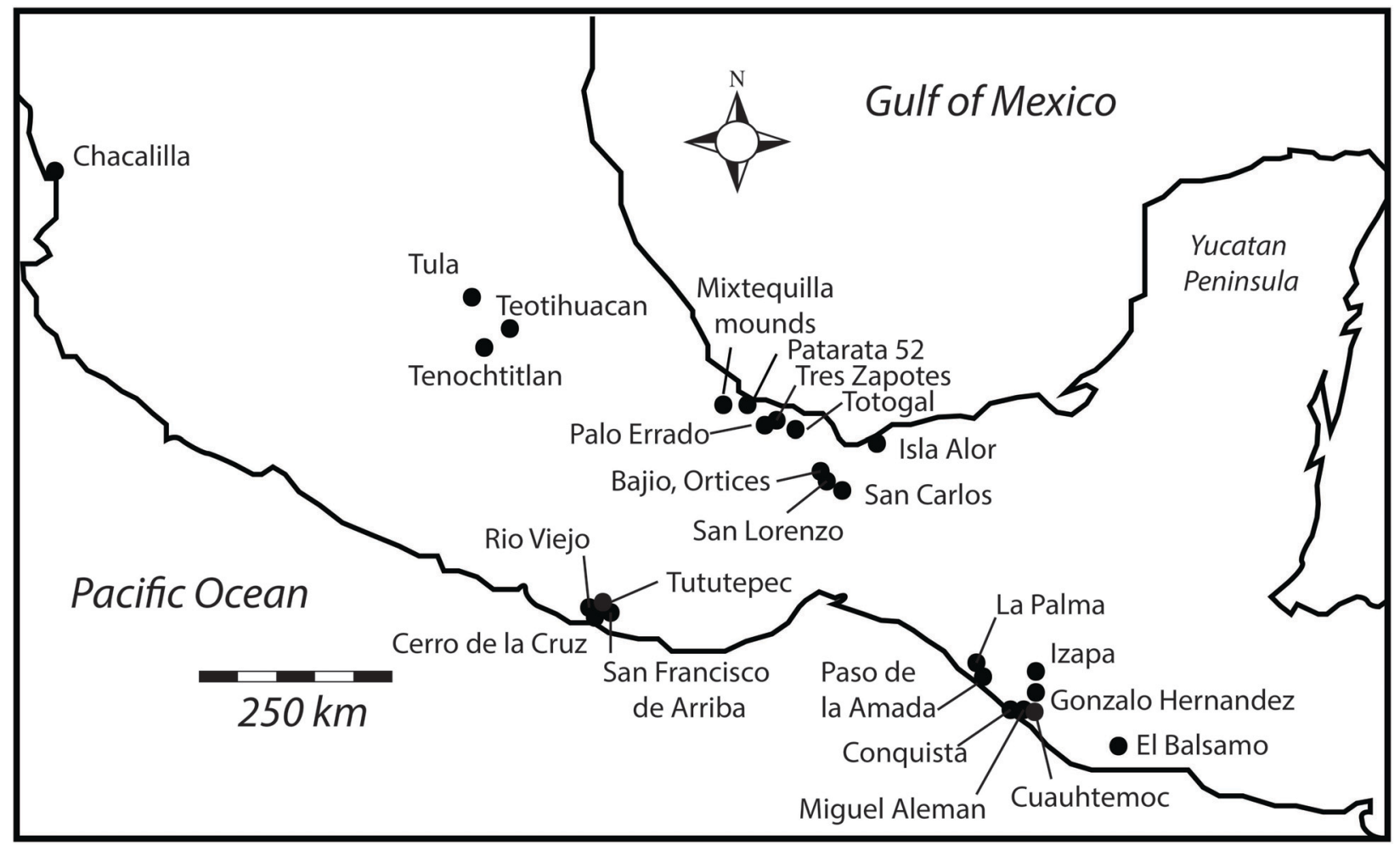

Figure 1. Map showing locations of three highland sites mentioned and of coastal sites analyzed. 


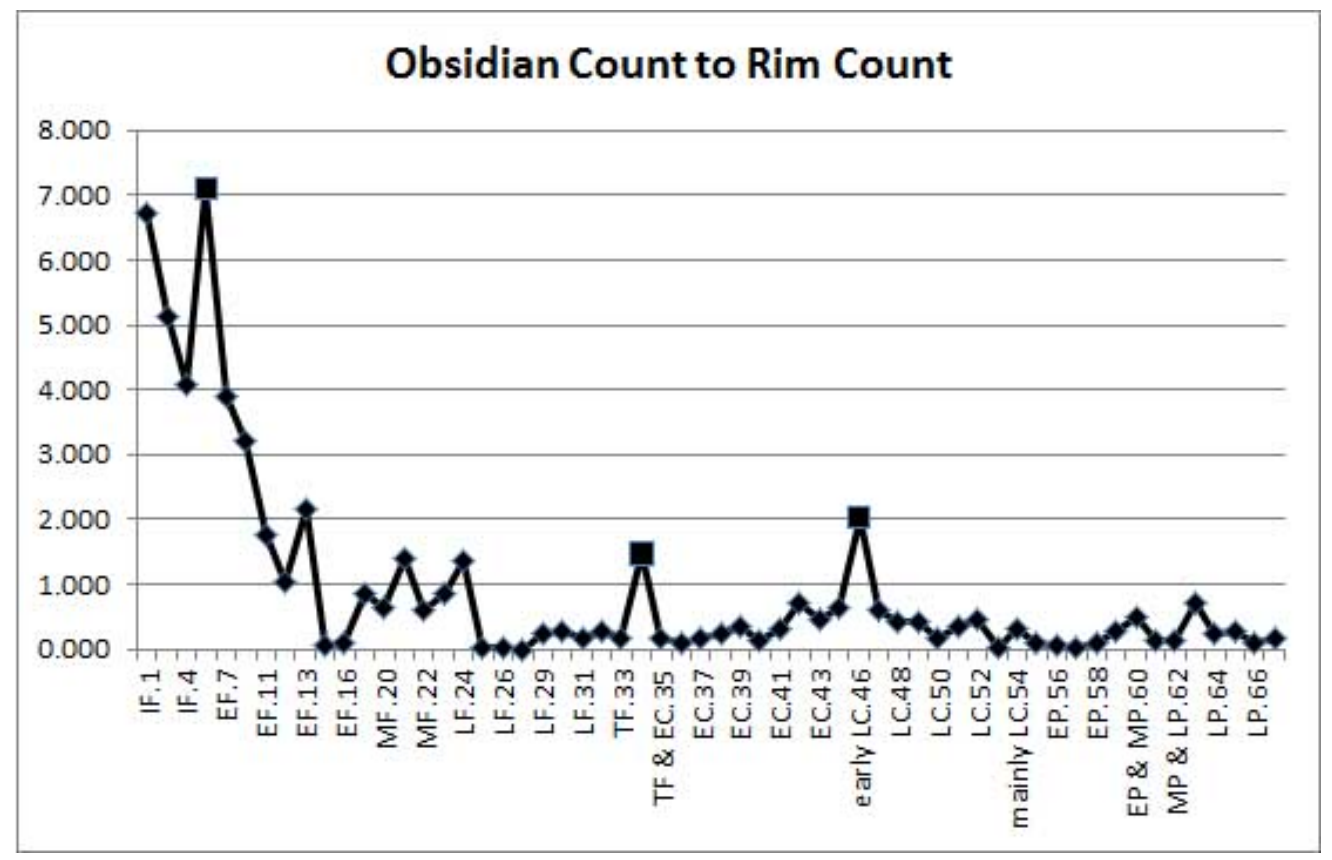

Figure 2a

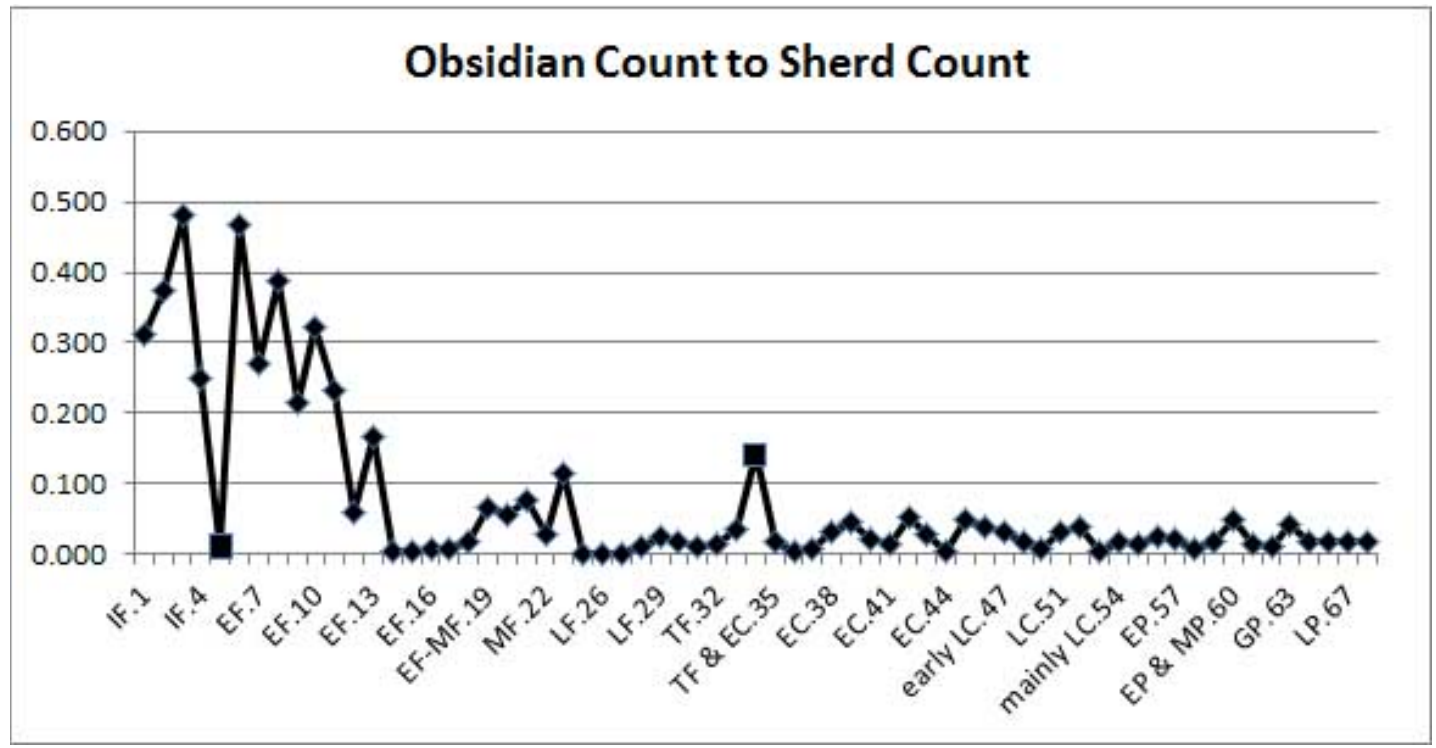

Figure $2 b$ 


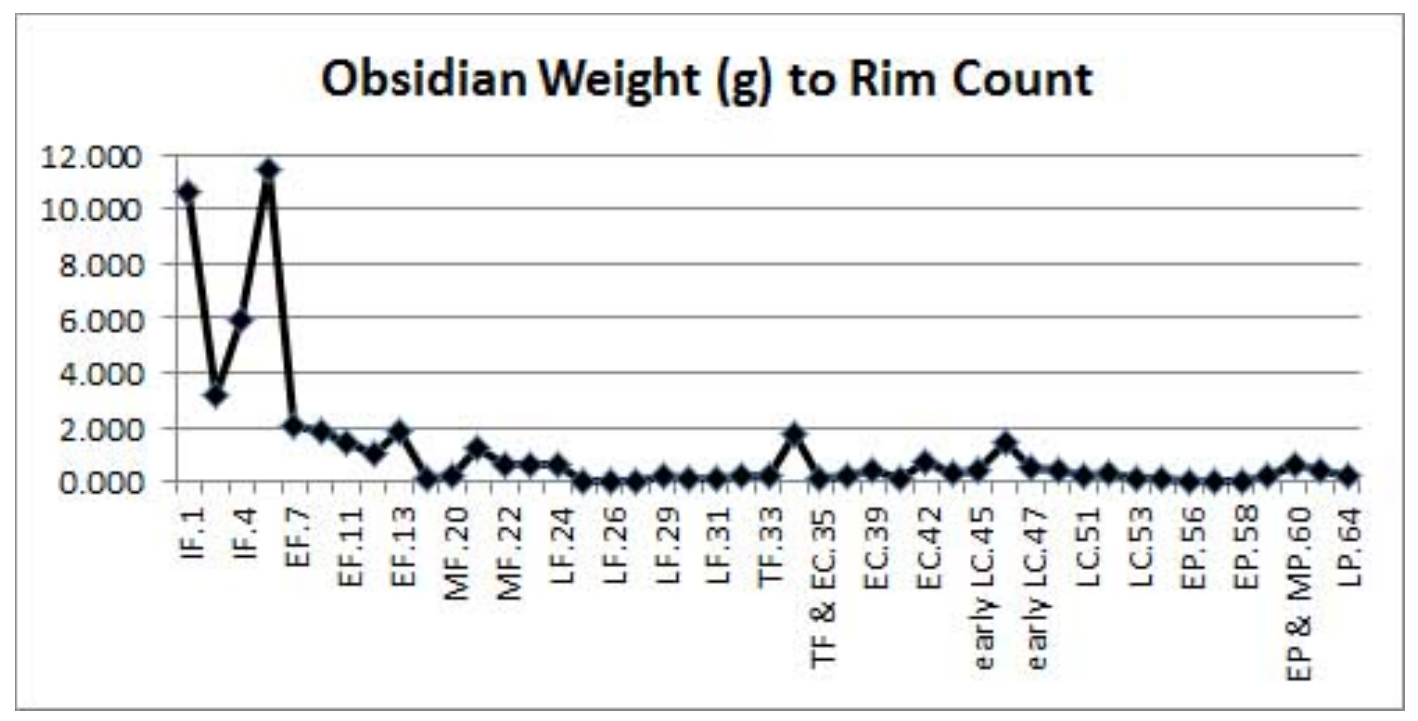

Figure 2c

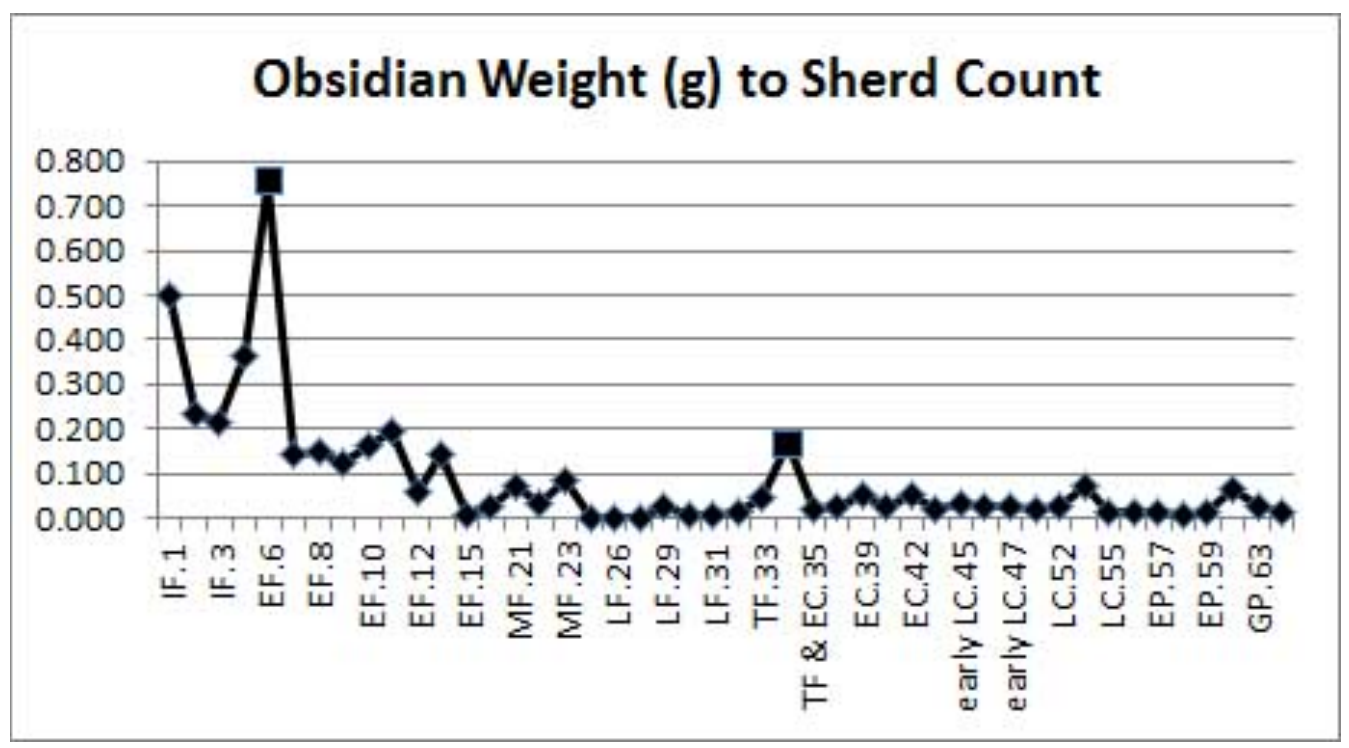

Figure 2d

Figure 2. Obsidian count and weight to rim and sherd counts, graphed as ratios. Black boxes indicate outlier values. 


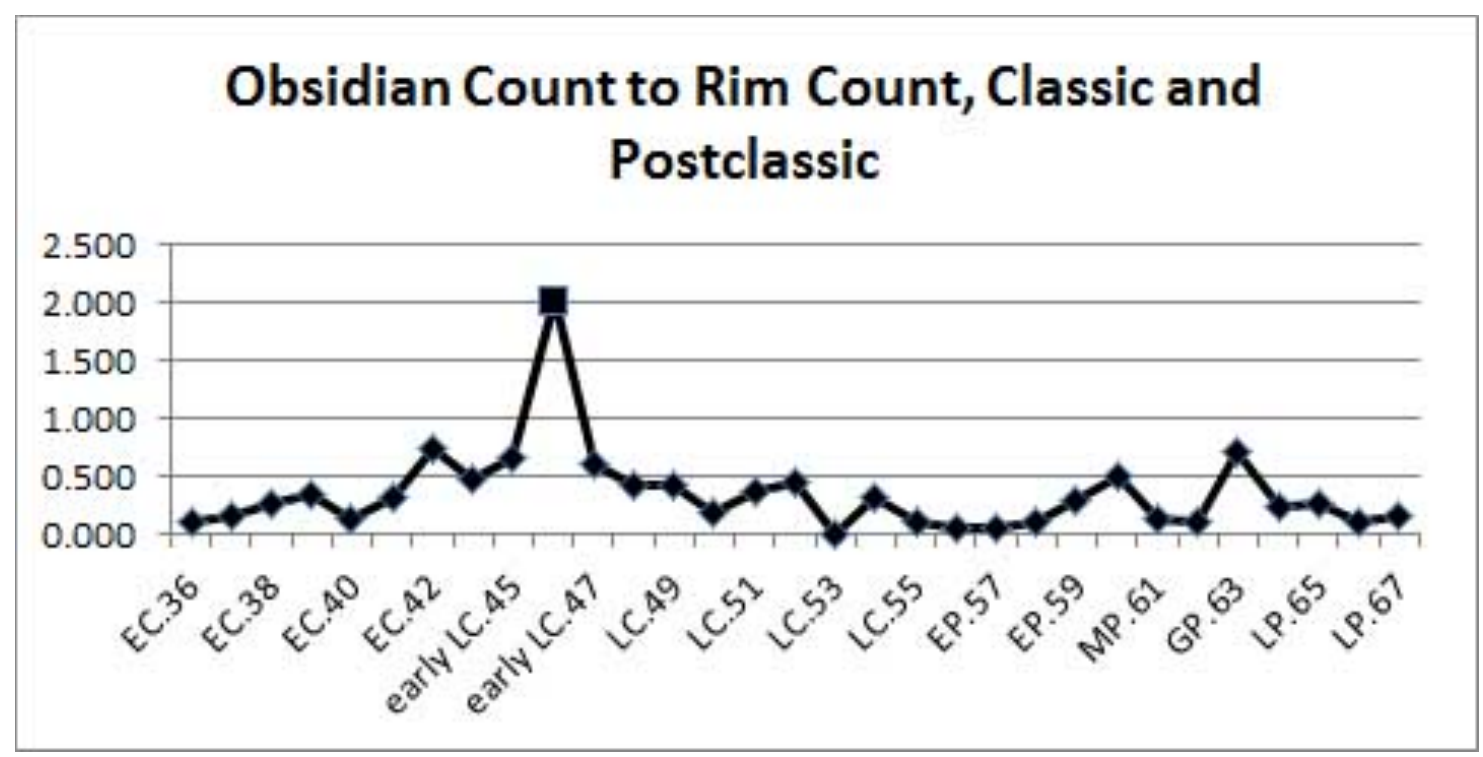

Figure 3a

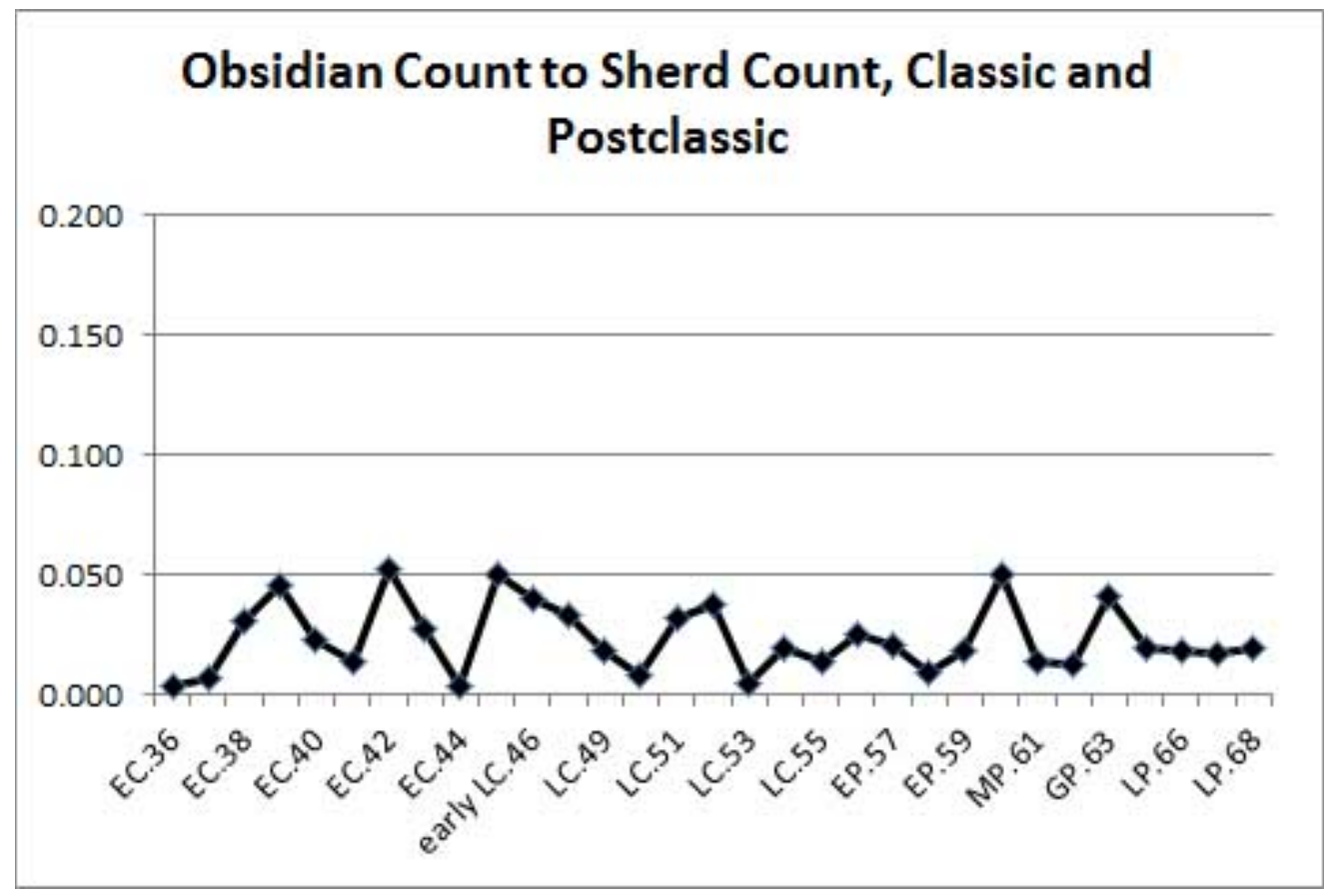

Figure $3 b$ 


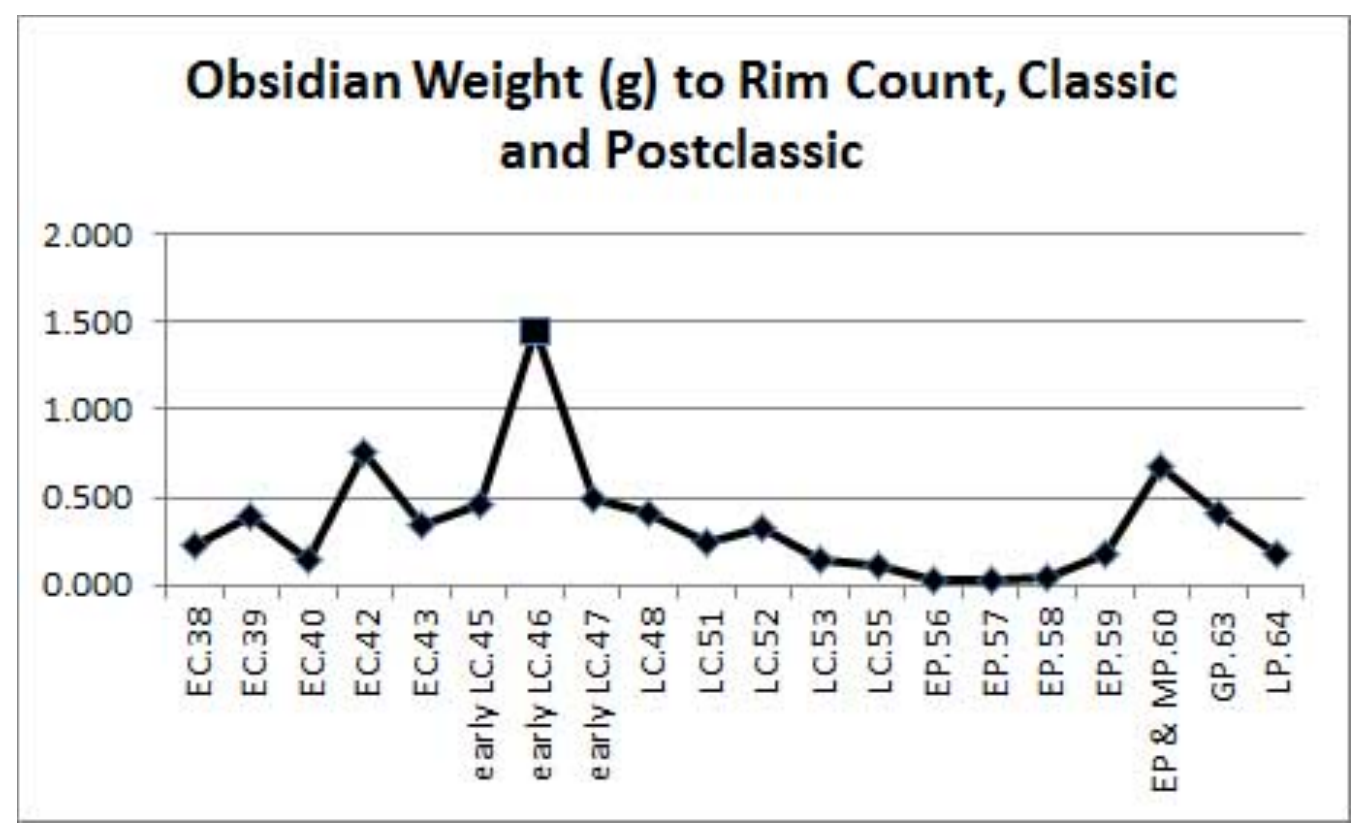

Figure 3c

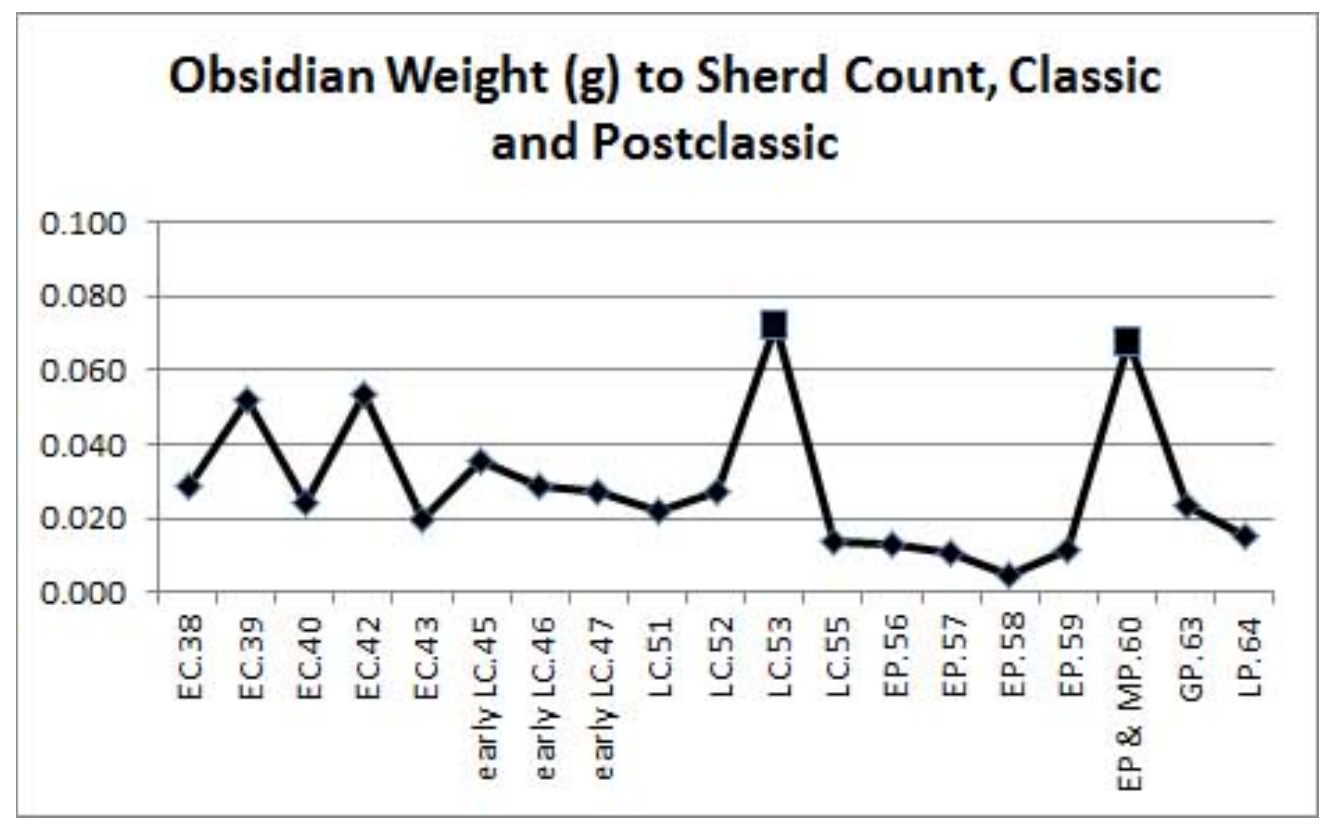

Figure 3d

Figure 3. Classic and Postclassic ratios of obsidian count and weight to rim and sherd counts. Outlier values are shown as black boxes. 


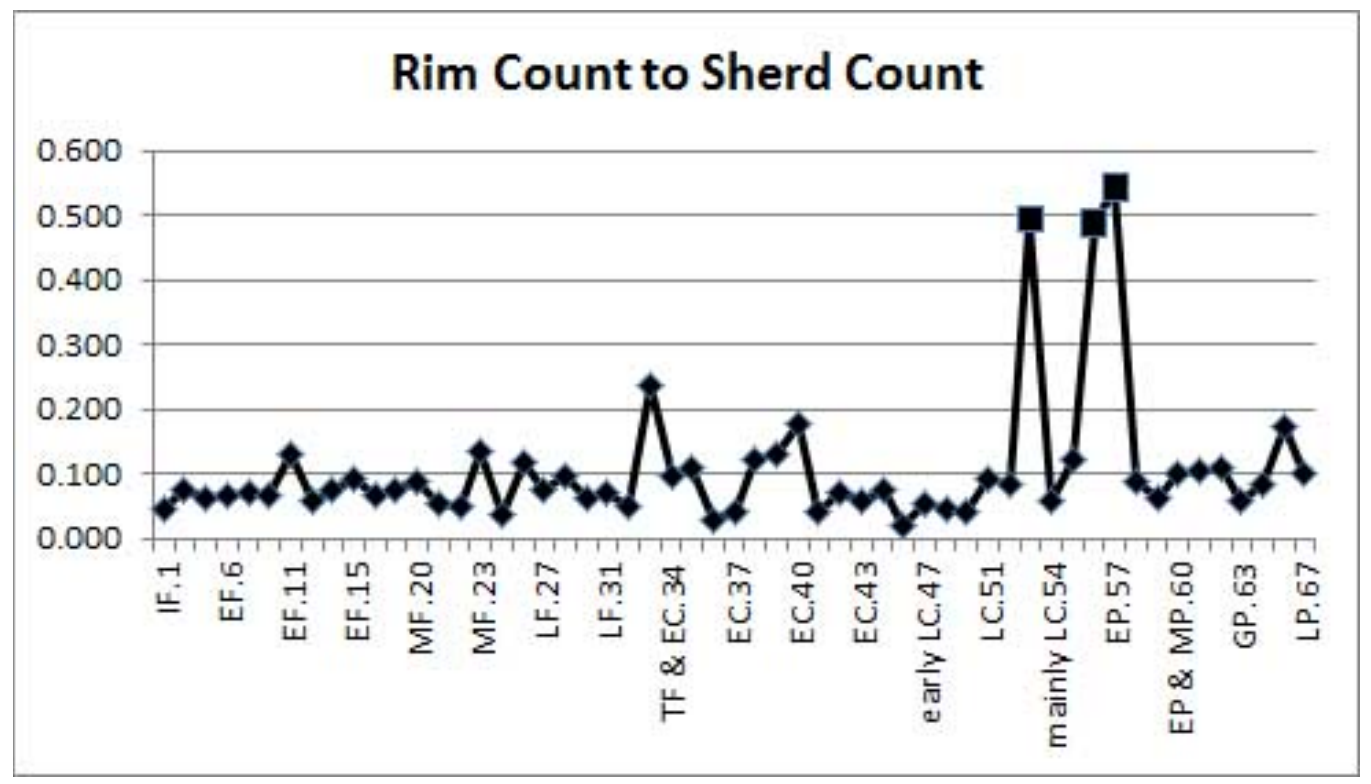

Figure 4a

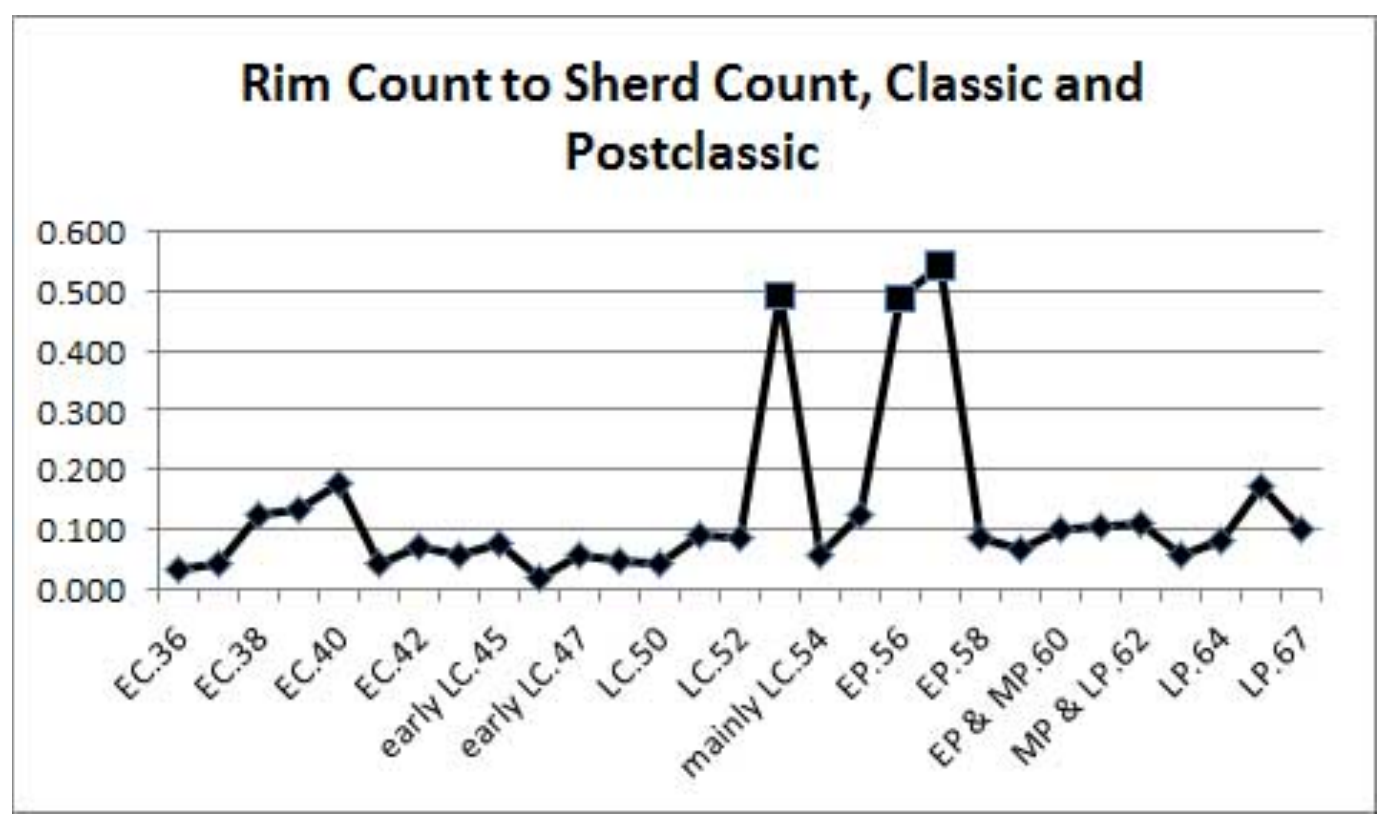

Figure $4 b$ 


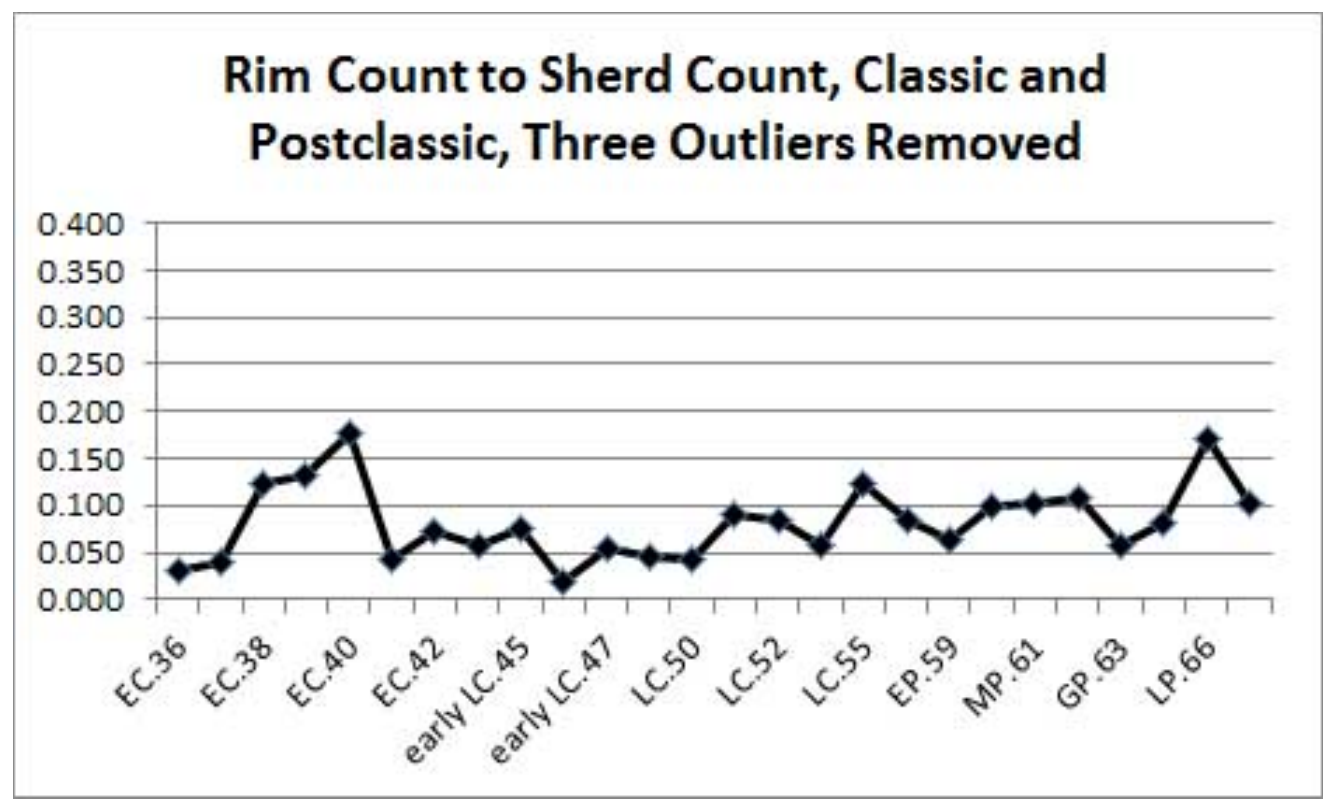

Figure 4c

Figure 4. Rim count to sherd count ratios, (a) all periods, (b) Classic and Postclassic periods, and (c) Classic and Postclassic periods with three outlier values removed. 
Table 1. Periods and number of assemblages.

\begin{tabular}{|l|c|r|}
\hline Major Mesoamerican Periods & Abbrev. & $\begin{array}{l}\text { Number of } \\
\text { Assemblages }\end{array}$ \\
\hline Initial Formative 2000-1500 BC & IF & 4 \\
\hline & IF/EF & 1 \\
\hline Early Formative 1500-900 BC & EF & 13 \\
\hline & EF/MF & 1 \\
\hline Middle Formative 900-500 BC & MF & 4 \\
\hline Late Formative 500-100 BC & LF & 8 \\
\hline Terminal Formative 100 BC-AD 300 & TF & 2 \\
\hline & TF\&EC & 2 \\
\hline Early Classic AD 300-600 & EC & 9 \\
\hline Late Classic AD 600-900 & LC & 11 \\
\hline Early Postclassic AD 900-1200 & EP & 4 \\
\hline & EP\&MP & 1 \\
\hline Middle Postclassic AD 1200-1350 & MP & 1 \\
\hline & MP\&LP & 1 \\
\hline Late Postclassic AD 1350-1521 & LP & 5 \\
\hline General Postclassic AD 900-1521 & GP & 1 \\
\hline Total & & 68 \\
\hline
\end{tabular}


Table 2. Data used in the analysis.

\begin{tabular}{|c|c|c|c|c|c|c|c|c|c|}
\hline \multirow[b]{2}{*}{$\begin{array}{l}\text { Period } \\
\& \text { ID } \\
\text { No. }\end{array}$} & \multirow[b]{2}{*}{$\begin{array}{c}\text { Site, phase name if } \\
\text { appropriate }\end{array}$} & \multirow[b]{2}{*}{$\begin{array}{c}\text { Contributing } \\
\text { Author }\end{array}$} & \multicolumn{7}{|c|}{ ARTIFACT DATA } \\
\hline & & & $\begin{array}{l}\text { Obsid } \\
\text { Count }\end{array}$ & $\begin{array}{l}\text { Obsid } \\
\text { Weight } \\
\text { (g) }\end{array}$ & $\begin{array}{l}\text { Chert } \\
\text { Count }\end{array}$ & $\begin{array}{l}\text { Other } \\
\text { Knap- } \\
\text { ped } \\
\text { Stone } \\
\text { Count }\end{array}$ & $\begin{array}{l}\text { Rim } \\
\text { Count }\end{array}$ & $\begin{array}{l}\text { All } \\
\text { Sherd } \\
\text { Count }\end{array}$ & $\begin{array}{c}\text { Relevant } \\
\text { Publications }\end{array}$ \\
\hline IF.1 & $\begin{array}{l}\text { Cuauhtemoc, Chis., Barra } \\
\text { phase }\end{array}$ & Rosenswig & 752 & 1195.8 & 0 & md & 112 & 2406 & $\begin{array}{l}\text { Rosenswig 2009, } \\
2010\end{array}$ \\
\hline IF.2 & $\begin{array}{l}\text { Paso de la Amada, Chis., } \\
\text { Locona phase, } 1700-1500 \text { BC }\end{array}$ & Lesure & 16755 & 10465.8 & $\begin{array}{l}\text { few } \\
\text { or } \\
\text { none }\end{array}$ & $\begin{array}{l}\text { few } \\
\text { or } \\
\text { none }\end{array}$ & 3276 & 44870 & $\begin{array}{l}\text { Lesure 1999, 2011; } \\
\text { Lesure and Blake, } \\
2002\end{array}$ \\
\hline IF.3 & $\begin{array}{l}\text { Paso de la Amada, Chis., } \\
\text { Locona phase, other } \\
\text { proveniences without rim } \\
\text { count }\end{array}$ & Lesure & 5923 & 2636.9 & $\begin{array}{l}\text { few } \\
\text { or } \\
\text { none }\end{array}$ & $\begin{array}{l}\text { few } \\
\text { or } \\
\text { none }\end{array}$ & md & 12301 & $\begin{array}{l}\text { Lesure 1999, 2011; } \\
\text { Lesure and Blake, } \\
2002\end{array}$ \\
\hline IF.4 & $\begin{array}{l}\text { Cuauhtemoc, Chis., Locona } \\
\text { phase }\end{array}$ & Rosenswig & 2126 & 3088.9 & 0 & md & 521 & 8535 & $\begin{array}{l}\text { Rosenswig 2009, } \\
2010\end{array}$ \\
\hline $\begin{array}{l}\text { IF- } \\
\text { EF.5 }\end{array}$ & $\begin{array}{l}\text { Conq 18, Chis., Early Conquista } \\
\text { complex, (Locona/Ocos) }\end{array}$ & Neff & 25 & md & 0 & 0 & md & 2375 & Neff 2014 \\
\hline EF.6 & $\begin{array}{l}\text { Cuauhtemoc, Chis., Ocos } \\
\text { phase }\end{array}$ & Rosenswig & 702 & 1132.5 & 0 & md & 99 & 1502 & $\begin{array}{l}\text { Rosenswig 2009, } \\
2010\end{array}$ \\
\hline EF.7 & $\begin{array}{l}\text { Paso de la Amada, Chis., Ocos } \\
\text { phase, } 1500-1400 \text { BC }\end{array}$ & Lesure & 9096 & 4698.4 & $\begin{array}{l}\text { few } \\
\text { or } \\
\text { none }\end{array}$ & $\begin{array}{l}\text { few } \\
\text { or } \\
\text { none }\end{array}$ & 2328 & 33647 & $\begin{array}{l}\text { Lesure 1999, 2011; } \\
\text { Lesure and Blake, } \\
2002\end{array}$ \\
\hline EF. 8 & $\begin{array}{l}\text { Paso de la Amada, Chis., Ocos } \\
\text { phase other proveniences } \\
\text { without rim count }\end{array}$ & Lesure & 18314 & 6998.4 & $\begin{array}{l}\text { few } \\
\text { or } \\
\text { none }\end{array}$ & $\begin{array}{l}\text { few } \\
\text { or } \\
\text { none }\end{array}$ & md & 47230 & $\begin{array}{l}\text { Lesure 1999, 2011; } \\
\text { Lesure and Blake, } \\
2002\end{array}$ \\
\hline EF.9 & $\begin{array}{l}\text { Paso de la Amada, Chis., } \\
\text { Cherla phase, } 1400-1300 \text { BC }\end{array}$ & Lesure & 6954 & 3916.3 & $\begin{array}{l}\text { few } \\
\text { or } \\
\text { none }\end{array}$ & $\begin{array}{l}\text { few } \\
\text { or } \\
\text { none }\end{array}$ & 2159 & 32233 & $\begin{array}{l}\text { Lesure 1999, 2011; } \\
\text { Lesure and Blake, } \\
2002\end{array}$ \\
\hline EF.10 & $\begin{array}{l}\text { Paso de la Amada, Chis., } \\
\text { Cherla phase, proveniences } \\
\text { without rim count }\end{array}$ & Lesure & 49965 & 24750.0 & $\begin{array}{l}\text { few } \\
\text { or } \\
\text { none }\end{array}$ & $\begin{array}{l}\text { few } \\
\text { or } \\
\text { none }\end{array}$ & md & 154554 & $\begin{array}{l}\text { Lesure 1999, 2011; } \\
\text { Lesure and Blake, } \\
2002\end{array}$ \\
\hline EF.11 & $\begin{array}{l}\text { Cuauhtemoc, Chis., Cherla } \\
\text { phase }\end{array}$ & Rosenswig & 499 & 411.1 & 0 & md & 283 & 2147 & $\begin{array}{l}\text { Rosenswig 2009, } \\
2010\end{array}$ \\
\hline
\end{tabular}




\begin{tabular}{|c|c|c|c|c|c|c|c|c|c|}
\hline EF.12 & $\begin{array}{l}\text { Cuauhtemoc, Chis., Cuadros } \\
\text { phase }\end{array}$ & Rosenswig & 168 & 162.7 & 0 & md & 162 & 2848 & $\begin{array}{l}\text { Rosenswig 2009, } \\
2010\end{array}$ \\
\hline EF.13 & $\begin{array}{l}\text { Cuauhtemoc, Chis., Jocotal } \\
\text { phase }\end{array}$ & Rosenswig & 239 & 208.2 & 0 & md & 110 & 1435 & $\begin{array}{l}\text { Rosenswig 2009, } \\
2010\end{array}$ \\
\hline EF.14 & $\begin{array}{l}\text { Conq } 18 \text { \& Conq1, Chis., Late } \\
\text { Conquista complex (Cuadros/ } \\
\text { Jocotal) }\end{array}$ & Neff & 23 & md & 0 & 0 & md & 4639 & Neff 2014 \\
\hline EF.15 & Isla Alor, Huimanguillo, Tab. & $\begin{array}{l}\text { Boxt, Raab, } \\
\text { \& González } \\
\text { Lauck }\end{array}$ & 40 & 52.6 & 1 & 36 & 664 & 7136 & $\begin{array}{l}\text { Raab, et al. 1994, } \\
\text { 1995, 2000; Boxt } \\
2012 \text { et al. }\end{array}$ \\
\hline EF.16 & $\begin{array}{l}\text { El Bajio, Ver., Stra. F \& H, } \\
\text { Profile Operation }\end{array}$ & & 509 & md & 5 & md & 4995 & 76153 & $\begin{array}{l}\text { Wendt 2003:187, } \\
512 ; 2010: 110,118\end{array}$ \\
\hline EF.17 & Paso de los Ortices, Ver. & & 19 & md & 0 & md & md & 3070 & $\begin{array}{l}\text { Wendt 2003:187, } \\
512 ; 2010: 110,118\end{array}$ \\
\hline EF.18 & $\begin{array}{l}\text { San Lorenzo, Ver., D5-9, D5- } \\
31, \text { B3-5 }\end{array}$ & & 447 & md & md & md & md & 24050 & $\begin{array}{l}\text { Wendt 2003:187, } \\
512 ; 2010: 110,118\end{array}$ \\
\hline $\begin{array}{l}\text { EF- } \\
\text { MF.19 }\end{array}$ & San Carlos, Ver. & Kruger & 694 & md & 5 & md & 804 & 10522 & $\begin{array}{l}\text { Robles Fernandez } \\
2004\end{array}$ \\
\hline MF.20 & $\begin{array}{l}\text { Tres Zapotes, Ver., Tres } \\
\text { Zapotes A\&B phases }\end{array}$ & Pool & 179 & 73.4 & 0 & 0 & 285 & 3224 & Pool et al. 2014 \\
\hline MF.21 & $\begin{array}{l}\text { Cuauhtemoc, Chis., Conchas } \\
\text { phase, } 1000-800 \text { BC }\end{array}$ & Rosenswig & 2021 & 1863.6 & 0 & md & 1453 & 26247 & $\begin{array}{l}\text { Rosenswig 2009, } \\
2010\end{array}$ \\
\hline MF.22 & $\begin{array}{l}\text { Cuauhtemoc, Chis., Conchas } \\
\text { phase, } 1000-800 \mathrm{BC}\end{array}$ & Rosenswig & 200 & 223.4 & 0 & md & 330 & 6705 & $\begin{array}{l}\text { Rosenswig 2009, } \\
2010\end{array}$ \\
\hline MF.23 & $\begin{array}{l}\text { Izapa, Chis., Escalon phase, } \\
600-400 \text { BC }\end{array}$ & Rosenswig & 286 & 217.2 & 0 & md & 341 & 2506 & $\begin{array}{l}\text { Rosenswig et al. } \\
2014\end{array}$ \\
\hline LF.24 & $\begin{array}{l}\text { El Balsamo, Guate., Field 2, } \\
\text { Stra. 1, 2, 3, Fea. 1a, Fea 1b, } \\
\text { Fea } 2 a\end{array}$ & Stark & 1603 & 705.5 & 0 & 0 & 1194 & md & $\begin{array}{l}\text { Heller 1986; Heller } \\
\text { and Stark 1989:57, } \\
61 ; \text { Stark } 1984\end{array}$ \\
\hline LF.25 & $\begin{array}{l}\text { Cerro de la Cruz, Oax., Fea } \\
\text { CC88 C-F5, Minizundo phase }\end{array}$ & Joyce & 74 & 77.8 & 2 & 0 & 1969 & 54104 & $\begin{array}{l}\text { Joyce 1991; Joyce et } \\
\text { al. 1995; Joyce et al. } \\
1998\end{array}$ \\
\hline LF.26 & $\begin{array}{l}\text { Rio Viejo, Oax., Fea RV88 B- } \\
\text { F50, Minizundo phase }\end{array}$ & Joyce & 7 & 5.1 & 2 & 0 & 967 & 8175 & $\begin{array}{l}\text { Joyce 1991; Joyce et } \\
\text { al. 1995; Joyce et al. } \\
1998\end{array}$ \\
\hline
\end{tabular}




\begin{tabular}{|c|c|c|c|c|c|c|c|c|c|}
\hline LF.27 & $\begin{array}{l}\text { Cerro de la Cruz, Oax., Fea } \\
\text { CC88 W-F7, Minizundo phase }\end{array}$ & Joyce & 0 & 0.0 & 0 & 0 & 314 & 4224 & $\begin{array}{l}\text { Joyce 1991; Joyce et } \\
\text { al. 1995; Joyce et al. } \\
1998\end{array}$ \\
\hline LF. 28 & $\begin{array}{l}\text { San Francisco de Arriba, Oax., } \\
\text { Operation 99F, Minizundo } \\
\text { phase }\end{array}$ & Workinger & 214 & md & 16 & 0 & md & 21825 & Workinger 2002 \\
\hline LF.29 & $\begin{array}{l}\text { Mounds } 693 \text { \& } 985 \text {, } \\
\text { Mixtequilla, Ver., Pozas phase }\end{array}$ & Stark & 635 & 683.5 & 0 & 0 & 2619 & 27224 & Stark 2001 \\
\hline LF.30 & $\begin{array}{l}\text { Tres Zapotes, Ver., Hueyapan } \\
\text { A phase }\end{array}$ & Pool & 28 & 16.2 & 0 & md & 109 & 1716 & Pool et al. 2014 \\
\hline LF.31 & $\begin{array}{l}\text { Tres Zapotes, Ver., Hueyapan } \\
\text { B phase }\end{array}$ & Pool & 60 & 45.4 & 0 & md & 362 & 5269 & Pool et al. 2014 \\
\hline TF.32 & $\begin{array}{l}\text { Tres Zapotes, Ver., Op 2B \& } \\
\text { Op3B, Nextepetl phase }\end{array}$ & Pool & 96 & 85.0 & 0 & md & 358 & 7012 & Pool et al. 2014 \\
\hline TF.33 & Palo Errado, Ver., Unit 4 & Knight & 54 & 64.8 & 0 & 0 & 361 & 1532 & $\begin{array}{l}\text { Knight and } \\
\text { Glascock } 2009\end{array}$ \\
\hline $\begin{array}{l}\text { TF \& } \\
\text { EC.34 }\end{array}$ & $\begin{array}{l}\text { Izapa, Chis., Jaritas phase, AD } \\
200-400\end{array}$ & Mendelsohn & 485 & 573.0 & md & md & 330 & 3437 & \\
\hline $\begin{array}{l}\text { TF \& } \\
\text { EC.35 }\end{array}$ & Mound 354, Mixtequilla, Ver. & Stark & 413 & 377.0 & 0 & 0 & 2436 & 22619 & Stark 2001 \\
\hline EC.36 & $\begin{array}{l}\text { Patarata 52, Ver., Camaron } 1 \\
\text { phase }\end{array}$ & Stark & 42 & md & 0 & 0 & 459 & 15321 & Stark 1977, 1989 \\
\hline EC.37 & $\begin{array}{l}\text { Patarata } 52, \text { Ver., Camaron } 2 \\
\text { phase }\end{array}$ & Stark & 116 & md & 0 & 0 & 720 & 17931 & Stark 1977, 1989 \\
\hline EC.38 & $\begin{array}{l}\text { Mound } 1126,44 \text { N33-35W, Fea } \\
28 \text { \& Str } 4 \text {, Mixtequilla, Ver., } \\
\text { Camaron } 1 \& 2 \text { phases }\end{array}$ & Stark & 59 & 55.0 & 0 & 0 & 234 & 1916 & Stark 2001 \\
\hline EC.39 & $\begin{array}{l}\text { Mound } 1126 \text {, Mixtequilla, } \\
\text { Ver., Camaron } 2 \& 3 \text { phases }\end{array}$ & Stark & 895 & 1045.0 & 0 & 0 & 2630 & 19961 & Stark 2001 \\
\hline EC.40 & $\begin{array}{l}\text { Mound 1055, Mixtequilla, } \\
\text { Ver., Camaron } 2 \& 3 \text { phases }\end{array}$ & Stark & 158 & 172.0 & 0 & 0 & 1239 & 7040 & Stark 2001 \\
\hline EC.41 & $\begin{array}{l}\text { Patarata } 52, \text { Ver., Camaron } 3 \\
\text { phase }\end{array}$ & Stark & 159 & md & 1 & 0 & 517 & 12253 & Stark 1977, 1989 \\
\hline EC.42 & Palo Errado, Ver., Unit 4 & Knight & 405 & 421.7 & 0 & 0 & 558 & 7830 & $\begin{array}{l}\text { Knight and } \\
\text { Glascock } 2009\end{array}$ \\
\hline
\end{tabular}




\begin{tabular}{|c|c|c|c|c|c|c|c|c|c|}
\hline EC.43 & Palo Errado, Ver., Unit 12 & Knight & 88 & 64.5 & 0 & 0 & 189 & 3301 & $\begin{array}{l}\text { Knight and } \\
\text { Glascock } 2009\end{array}$ \\
\hline EC.44 & $\begin{array}{l}\text { San Francisco de Arriba, Oax., } \\
\text { Operation 99B, Coyuche phase }\end{array}$ & Workinger & 58 & md & 1 & 0 & $\mathrm{md}$ & 16164 & Workinger 2002 \\
\hline $\begin{array}{l}\text { early } \\
\text { LC. } 45\end{array}$ & Palo Errado, Ver., Unit 4 & Knight & 104 & 74.1 & 0 & 0 & 159 & 2097 & $\begin{array}{l}\text { Knight and } \\
\text { Glascock } 2009\end{array}$ \\
\hline $\begin{array}{l}\text { early } \\
\text { LC. } 46\end{array}$ & Palo Errado, Ver., Unit 6 & Knight & 208 & 149.5 & 0 & 0 & 103 & 5174 & $\begin{array}{l}\text { Knight and } \\
\text { Glascock } 2009\end{array}$ \\
\hline $\begin{array}{l}\text { early } \\
\text { LC. } 47\end{array}$ & Palo Errado, Ver., Unit 12 & Knight & 140 & 115.1 & 0 & 0 & 233 & 4228 & $\begin{array}{l}\text { Knight and } \\
\text { Glascock } 2009\end{array}$ \\
\hline LC. 48 & $\begin{array}{l}\text { Mound 1055, Mixtequilla, } \\
\text { Ver., Early Limon phase }\end{array}$ & Stark & 182 & 181.0 & 0 & 0 & 441 & $\mathrm{md}$ & Stark 2001 \\
\hline LC. 49 & $\begin{array}{l}\text { Patarata } 52 \text {, Ver., Early Limon } \\
\text { phase }\end{array}$ & Stark & 236 & $\mathrm{md}$ & 0 & 0 & 567 & 12692 & Stark 1977, 1989 \\
\hline LC. 50 & $\begin{array}{l}\text { Patarata } 52, \text { Ver., Late Limon } \\
\text { phase }\end{array}$ & Stark & 51 & md & 0 & 0 & 291 & 7011 & Stark 1977, 1989 \\
\hline LC.51 & $\begin{array}{l}\text { Mound } 1055 \text {, Mixtequilla, } \\
\text { Ver., Late Limon phase }\end{array}$ & Stark & 420 & 289.0 & 0 & 0 & 1189 & 13093 & Stark 2001 \\
\hline LC.52 & $\begin{array}{l}\text { Mound 1126, Mixtequilla, } \\
\text { Ver., plow zones, Late Limon } \\
\text { phase }\end{array}$ & Stark & 183 & 133.0 & 0 & 0 & 407 & 4836 & Stark 2001 \\
\hline LC.53 & $\begin{array}{l}\text { Miguel Aleman, Chis., Units 4a } \\
\text { and } 4 \mathrm{~b}\end{array}$ & $\begin{array}{l}\text { Navarro- } \\
\text { Castillo }\end{array}$ & 3 & 44 & 0 & 0 & 300 & 608 & $\begin{array}{l}\text { Navarro-Castillo } \\
2014,2015\end{array}$ \\
\hline $\begin{array}{l}\text { mainly } \\
\text { LC.54 }\end{array}$ & $\begin{array}{l}\text { Chacalapan, Ver., all test pits } \\
\text { except pits } 1,4,13,18\end{array}$ & & 707 & md & 0 & 0 & 2209 & 37684 & $\begin{array}{l}\text { Esquivias 2003:219- } \\
226,319-348\end{array}$ \\
\hline LC. 55 & Totogal, Ver., Chaneque phase & Venter & 37 & 37.7 & 0 & 0 & 337 & 2724 & Venter 2008 \\
\hline EP.56 & $\begin{array}{l}\text { Rio Viejo, Oax., F23/24 } \\
\text { midden, Operation A, earlier } \\
\text { Yugüe phase }\end{array}$ & $\begin{array}{l}\text { Hedgepeth- } \\
\text { Balkin \& } \\
\text { Williams }\end{array}$ & 43 & 22.29 & 4 & 1 & 853 & 1749 & $\begin{array}{l}\text { Hedgepeth 2009, } \\
\text { 2010; Joyce et al. } \\
\text { 2001; Joyce et al. } \\
\text { 2014; Williams } 2012\end{array}$ \\
\hline
\end{tabular}




\begin{tabular}{|c|c|c|c|c|c|c|c|c|c|}
\hline EP.57 & $\begin{array}{l}\text { Rio Viejo, Oax., F14 midden, } \\
\text { Operation A, later Yugüe } \\
\text { phase }\end{array}$ & $\begin{array}{l}\text { Hedgepeth- } \\
\text { Balkin \& } \\
\text { Williams }\end{array}$ & 11 & 5.9 & 2 & 0 & 297 & 547 & $\begin{array}{l}\text { Hedgepeth 2009, } \\
\text { 2010; Joyce et al. } \\
\text { 2001; Joyce et al. } \\
\text { 2014; Williams } 2012\end{array}$ \\
\hline EP.58 & $\begin{array}{l}\text { Rio Viejo, Oax., Operation B } \\
\text { neigborhood, Yugüe phase }\end{array}$ & King & 1061 & 527.9 & 56 & 9 & 10043 & 116943 & $\begin{array}{l}\text { King 2003, } \\
\text { 2008:259-263 }\end{array}$ \\
\hline EP.59 & Totogal, Ver., Vigía Phase & Venter & 33 & 21.4 & 0 & 1 & 120 & 1875 & Venter 2008 \\
\hline $\begin{array}{l}\text { EP \& } \\
\text { MP. } 60\end{array}$ & $\begin{array}{l}\text { Chacalilla, Nay., Fea 10, 15, 67, } \\
\text { and South Plaza Group }\end{array}$ & Ohnersorgen & 5336 & 7291.0 & 0 & md & 10797 & 107607 & \\
\hline MP.61 & $\begin{array}{l}\text { Tututepec, Oax., Yucu Dzaa } \\
\text { Residence A, AD 1300s }\end{array}$ & Levine & 838 & md & 23 & 8 & 6297 & 60816 & $\begin{array}{l}\text { Levine 2007; } \\
\text { 2011:33; 2014:165 }\end{array}$ \\
\hline $\begin{array}{l}\text { MP \& } \\
\text { LP.62 }\end{array}$ & $\begin{array}{l}\text { Tututepec, Oax., Yucu Dzaa } \\
\text { Residence C, AD 1100-1522 }\end{array}$ & Levine & 71 & md & 2 & 0 & 639 & 5835 & $\begin{array}{l}\text { Levine 2011:33; } \\
\text { 2014:165 }\end{array}$ \\
\hline GP.63 & Isla Alor, Huimanguillo, Tab. & $\begin{array}{l}\text { Boxt, Raab, } \\
\text { \& González } \\
\text { Lauck }\end{array}$ & 240 & 135.7 & 2 & 36 & 336 & 5831 & $\begin{array}{l}\text { Boxt } 2012 \text { et al.; } \\
\text { Raab, et al. 1994, } \\
\text { 1995, } 2000\end{array}$ \\
\hline LP.64 & Totogal, Ver.,Totogal phase & Venter & 118 & 91.4 & 0 & 2 & 499 & 6026 & Venter 2008 \\
\hline LP.65 & La Palma, Chis. & Voorhies & 119 & md & md & md & 463 & md & $\begin{array}{l}\text { Voorhies and Gasco } \\
2004\end{array}$ \\
\hline LP.66 & Gonzalo Hernandez, Chis. & Gasco & 157 & md & 0 & 0 & 1502 & 8712 & Gasco 2015 \\
\hline LP.67 & $\begin{array}{l}\text { Tututepec, Oax., Yucu Dzaa } \\
\text { Residence B, AD 1400s }\end{array}$ & Levine & 282 & md & 8 & 0 & 1740 & 17090 & $\begin{array}{l}\text { Levine 2007; } \\
\text { 2011:33; 2014:165 }\end{array}$ \\
\hline LP.68 & $\begin{array}{l}\text { San Francisco de Arriba, Oax., } \\
\text { Operation 99J, Yucudzaa } \\
\text { phase }\end{array}$ & Workinger & 35 & md & 0 & 0 & md & 1805 & Workinger 2002 \\
\hline
\end{tabular}

Note: $\mathrm{md}=$ missing data (shaded

boxes) 
Table 3. Ratio data.

Ratios (division by 0 shown as 0 )

\begin{tabular}{|c|c|c|c|c|c|c|}
\hline $\begin{array}{l}\text { Period } \\
\& I D \\
\text { No. }\end{array}$ & $\begin{array}{l}\text { Site, Phase Name If } \\
\text { Appropriate }\end{array}$ & $\begin{array}{l}\text { Obsid } \\
\text { Ct/ } \\
\text { Rims }\end{array}$ & $\begin{array}{l}\text { Obsid } \\
\text { Ct/ } \\
\text { Sherds }\end{array}$ & $\begin{array}{l}\text { Obsid } \\
\text { Wt/ } \\
\text { Rims } \\
\end{array}$ & $\begin{array}{l}\text { Obsid } \\
\text { Wt/ } \\
\text { Sherds }\end{array}$ & $\begin{array}{l}\text { Rims/ } \\
\text { Sherds }\end{array}$ \\
\hline IF.1 & Cuauhtemoc, Chis., Barra phase & 6.71 & 0.31 & 10.68 & 0.50 & 0.05 \\
\hline IF.2 & $\begin{array}{l}\text { Paso de la Amada, Chis., Locona } \\
\text { phase, } 1700-1500 \text { BC }\end{array}$ & 5.11 & 0.37 & 3.19 & 0.23 & 0.07 \\
\hline IF.3 & $\begin{array}{l}\text { Paso de la Amada, Chis., Locona } \\
\text { phase, other proveniences } \\
\text { without rim count }\end{array}$ & & 0.48 & & 0.21 & \\
\hline IF.4 & $\begin{array}{l}\text { Cuauhtemoc, Chis., Locona } \\
\text { phase }\end{array}$ & 4.08 & 0.25 & 5.93 & 0.36 & 0.06 \\
\hline IF-EF. 5 & $\begin{array}{l}\text { Conq } 18 \text {, Chis., Early Conquista } \\
\text { complex, (Locona/Ocos) }\end{array}$ & & 0.01 & & & \\
\hline EF.6 & Cuauhtemoc, Chis., Ocos phase & 7.09 & 0.47 & 11.44 & 0.75 & 0.07 \\
\hline EF.7 & $\begin{array}{l}\text { Paso de la Amada, Chis., Ocos } \\
\text { phase, } 1500-1400 \text { BC }\end{array}$ & 3.91 & 0.27 & 2.02 & 0.14 & 0.07 \\
\hline EF.8 & $\begin{array}{l}\text { Paso de la Amada, Chis., Ocos } \\
\text { phase other proveniences } \\
\text { without rim count }\end{array}$ & & 0.39 & & 0.15 & \\
\hline EF.9 & $\begin{array}{l}\text { Paso de la Amada, Chis., Cherla } \\
\text { phase, } 1400-1300 \mathrm{BC}\end{array}$ & 3.22 & 0.22 & 1.81 & 0.12 & 0.07 \\
\hline EF.10 & $\begin{array}{l}\text { Paso de la Amada, Chis., Cherla } \\
\text { phase, proveniences without } \\
\text { rim count }\end{array}$ & & 0.32 & & 0.16 & \\
\hline EF.11 & $\begin{array}{l}\text { Cuauhtemoc, Chis., Cherla } \\
\text { phase }\end{array}$ & 1.76 & 0.23 & 1.45 & 0.19 & 0.13 \\
\hline EF.12 & $\begin{array}{l}\text { Cuauhtemoc, Chis., Cuadros } \\
\text { phase }\end{array}$ & 1.04 & 0.06 & 1.00 & 0.06 & 0.06 \\
\hline EF.13 & $\begin{array}{l}\text { Cuauhtemoc, Chis., Jocotal } \\
\text { phase }\end{array}$ & 2.17 & 0.17 & 1.89 & 0.15 & 0.08 \\
\hline EF.14 & $\begin{array}{l}\text { Conq } 18 \text { \& Conq1, Chis., Late } \\
\text { Conquista complex (Cuadros/ } \\
\text { Jocotal) }\end{array}$ & & 0.00 & & & \\
\hline EF.15 & Isla Alor, Huimanguillo, Tab. & 0.06 & 0.01 & 0.08 & 0.01 & 0.09 \\
\hline EF.16 & $\begin{array}{l}\text { El Bajio, Ver., Stra. F \& H, } \\
\text { Profile Operation }\end{array}$ & 0.10 & 0.01 & & & 0.07 \\
\hline EF.17 & Paso de los Ortices, Ver. & & 0.01 & & & \\
\hline EF.18 & $\begin{array}{l}\text { San Lorenzo, Ver., D5-9, D5-31, } \\
\text { B3-5 }\end{array}$ & & 0.02 & & & \\
\hline $\begin{array}{c}\text { EF- } \\
\text { MF.19 }\end{array}$ & San Carlos, Ver. & 0.86 & 0.07 & & & 0.08 \\
\hline MF.20 & $\begin{array}{l}\text { Tres Zapotes, Ver., Tres Zapotes } \\
\text { A\&B phases }\end{array}$ & 0.63 & 0.06 & 0.26 & 0.02 & 0.09 \\
\hline MF.21 & $\begin{array}{l}\text { Cuauhtemoc, Chis., Conchas } \\
\text { phase, } 1000-800 \mathrm{BC}\end{array}$ & 1.39 & 0.08 & 1.28 & 0.07 & 0.06 \\
\hline MF.22 & $\begin{array}{l}\text { Cuauhtemoc, Chis., Conchas } \\
\text { phase, } 1000-800 \text { BC }\end{array}$ & 0.61 & 0.03 & 0.68 & 0.03 & 0.05 \\
\hline
\end{tabular}




\begin{tabular}{|c|c|c|c|c|c|c|}
\hline MF.23 & $\begin{array}{l}\text { Izapa, Chis., Escalon phase, } \\
600-400 \text { BC }\end{array}$ & 0.84 & 0.11 & 0.64 & 0.09 & 0.14 \\
\hline LF.24 & $\begin{array}{l}\text { El Balsamo, Guate., Field 2, } \\
\text { Stra. 1, 2, 3, Fea. 1a, Fea 1b, } \\
\text { Fea 2a }\end{array}$ & 1.34 & & 0.59 & & \\
\hline LF. 25 & $\begin{array}{l}\text { Cerro de la Cruz, Oax., Fea CC88 } \\
\text { C-F5, Minizundo phase }\end{array}$ & 0.04 & 0.00 & 0.04 & 0.00 & 0.04 \\
\hline LF.26 & $\begin{array}{l}\text { Rio Viejo, Oax., Fea RV88 B-F50, } \\
\text { Minizundo phase }\end{array}$ & 0.01 & 0.00 & 0.01 & 0.00 & 0.12 \\
\hline LF. 27 & $\begin{array}{l}\text { Cerro de la Cruz, Oax., Fea CC88 } \\
\text { W-F7, Minizundo phase }\end{array}$ & 0.00 & 0.00 & 0.00 & 0.00 & 0.07 \\
\hline LF. 28 & $\begin{array}{l}\text { San Francisco de Arriba, Oax., } \\
\text { Operation 99F, Minizundo } \\
\text { phase }\end{array}$ & & 0.01 & & & \\
\hline LF.29 & $\begin{array}{l}\text { Mounds } 693 \& 985 \\
\text { Mixtequilla, Ver., Pozas phase }\end{array}$ & 0.24 & 0.02 & 0.26 & 0.03 & 0.10 \\
\hline LF.30 & $\begin{array}{l}\text { Tres Zapotes, Ver., Hueyapan A } \\
\text { phase }\end{array}$ & 0.26 & 0.02 & 0.15 & 0.01 & 0.06 \\
\hline LF.31 & $\begin{array}{l}\text { Tres Zapotes, Ver., Hueyapan B } \\
\text { phase }\end{array}$ & 0.17 & 0.01 & 0.13 & 0.01 & 0.07 \\
\hline TF.32 & $\begin{array}{l}\text { Tres Zapotes, Ver., Op 2B \& } \\
\text { Op3B, Nextepetl phase }\end{array}$ & 0.27 & 0.01 & 0.24 & 0.01 & 0.05 \\
\hline TF.33 & Palo Errado, Ver., Unit 4 & 0.15 & 0.04 & 0.18 & 0.04 & 0.24 \\
\hline $\begin{array}{l}\text { TF \& } \\
\text { EC.34 }\end{array}$ & $\begin{array}{l}\text { Izapa, Chis., Jaritas phase, AD } \\
200-400\end{array}$ & 1.47 & 0.14 & 1.74 & 0.17 & 0.10 \\
\hline $\begin{array}{l}\text { TF \& } \\
\text { EC. } 35 \\
\end{array}$ & Mound 354, Mixtequilla, Ver. & 0.17 & 0.02 & 0.15 & 0.02 & 0.11 \\
\hline EC.36 & $\begin{array}{l}\text { Patarata 52, Ver., Camaron } 1 \\
\text { phase }\end{array}$ & 0.09 & 0.00 & & & 0.03 \\
\hline EC.37 & $\begin{array}{l}\text { Patarata 52, Ver., Camaron } 2 \\
\text { phase }\end{array}$ & 0.16 & 0.01 & & & 0.04 \\
\hline EC.38 & $\begin{array}{l}\text { Mound } 1126,44 \text { N33-35W, Fea } \\
28 \& \text { Str } 4 \text {, Mixtequilla, Ver., } \\
\text { Camaron } 1 \& 2 \text { phases }\end{array}$ & 0.25 & 0.03 & 0.24 & 0.03 & 0.12 \\
\hline EC.39 & $\begin{array}{l}\text { Mound } 1126 \text {, Mixtequilla, Ver., } \\
\text { Camaron } 2 \& 3 \text { phases }\end{array}$ & 0.34 & 0.04 & 0.40 & 0.05 & 0.13 \\
\hline EC.40 & $\begin{array}{l}\text { Mound } 1055 \text {, Mixtequilla, Ver., } \\
\text { Camaron } 2 \& 3 \text { phases }\end{array}$ & 0.13 & 0.02 & 0.14 & 0.02 & 0.18 \\
\hline EC.41 & $\begin{array}{l}\text { Patarata 52, Ver., Camaron } 3 \\
\text { phase }\end{array}$ & 0.31 & 0.01 & & & 0.04 \\
\hline EC.42 & Palo Errado, Ver., Unit 4 & 0.73 & 0.05 & 0.76 & 0.05 & 0.07 \\
\hline EC.43 & Palo Errado, Ver., Unit 12 & 0.47 & 0.03 & 0.34 & 0.02 & 0.06 \\
\hline EC.44 & $\begin{array}{l}\text { San Francisco de Arriba, Oax., } \\
\text { Operation 99B, Coyuche phase }\end{array}$ & & 0.00 & & & \\
\hline $\begin{array}{l}\text { early } \\
\text { LC. } 45\end{array}$ & Palo Errado, Ver., Unit 4 & 0.65 & 0.05 & 0.47 & 0.04 & 0.08 \\
\hline $\begin{array}{l}\text { early } \\
\text { LC. } 46\end{array}$ & Palo Errado, Ver., Unit 6 & 2.02 & 0.04 & 1.45 & 0.03 & 0.02 \\
\hline
\end{tabular}




\begin{tabular}{|c|c|c|c|c|c|c|}
\hline $\begin{array}{l}\text { early } \\
\text { LC. } 47\end{array}$ & Palo Errado, Ver., Unit 12 & 0.60 & 0.03 & 0.49 & 0.03 & 0.06 \\
\hline LC. 48 & $\begin{array}{l}\text { Mound 1055, Mixtequilla, Ver., } \\
\text { Early Limon phase }\end{array}$ & 0.41 & & 0.41 & & \\
\hline LC. 49 & $\begin{array}{l}\text { Patarata 52, Ver., Early Limon } \\
\text { phase }\end{array}$ & 0.42 & 0.02 & & & 0.04 \\
\hline LC. 50 & $\begin{array}{l}\text { Patarata 52, Ver., Late Limon } \\
\text { phase }\end{array}$ & 0.18 & 0.01 & & & 0.04 \\
\hline LC.51 & $\begin{array}{l}\text { Mound 1055, Mixtequilla, Ver., } \\
\text { Late Limon phase }\end{array}$ & 0.35 & 0.03 & 0.24 & 0.02 & 0.09 \\
\hline LC.52 & $\begin{array}{l}\text { Mound 1126, Mixtequilla, Ver., } \\
\text { plow zones, Late Limon phase }\end{array}$ & 0.45 & 0.04 & 0.33 & 0.03 & 0.08 \\
\hline LC. 53 & $\begin{array}{l}\text { Miguel Aleman, Chis., Units } 4 a \\
\text { and } 4 \mathrm{~b}\end{array}$ & 0.01 & 0.00 & 0.15 & 0.07 & 0.49 \\
\hline $\begin{array}{l}\text { mainly } \\
\text { LC.54 }\end{array}$ & $\begin{array}{l}\text { Chacalapan, Ver., all test pits } \\
\text { except pits } 1,4,13,18\end{array}$ & 0.32 & 0.02 & & & 0.06 \\
\hline LC. 55 & Totogal, Ver., Chaneque phase & 0.11 & 0.01 & 0.11 & 0.01 & 0.12 \\
\hline EP. 56 & $\begin{array}{l}\text { Rio Viejo, Oax., F23/24 midden, } \\
\text { Operation A, earlier Yugüe } \\
\text { phase }\end{array}$ & 0.05 & 0.02 & 0.03 & 0.01 & 0.49 \\
\hline EP. 57 & $\begin{array}{l}\text { Rio Viejo, Oax., F14 midden, } \\
\text { Operation A, later Yugüe phase }\end{array}$ & 0.04 & 0.02 & 0.02 & 0.01 & 0.54 \\
\hline EP.58 & $\begin{array}{l}\text { Rio Viejo, Oax., Operation B } \\
\text { neigborhood, Yugüe phase }\end{array}$ & 0.11 & 0.01 & 0.05 & 0.00 & 0.09 \\
\hline EP.59 & Totogal, Ver., Vigía Phase & 0.28 & 0.02 & 0.18 & 0.01 & 0.06 \\
\hline $\begin{array}{c}\text { EP \& } \\
\text { MP.60 }\end{array}$ & $\begin{array}{l}\text { Chacalilla, Nay., Fea 10, 15, 67, } \\
\text { and South Plaza Group }\end{array}$ & 0.49 & 0.05 & 0.68 & 0.07 & 0.10 \\
\hline MP.61 & $\begin{array}{l}\text { Tututepec, Oax., Yucu Dzaa } \\
\text { Residence A, AD 1300s }\end{array}$ & 0.13 & 0.01 & & & 0.10 \\
\hline $\begin{array}{l}\text { MP \& } \\
\text { LP.62 }\end{array}$ & $\begin{array}{l}\text { Tututepec, Oax., Yucu Dzaa } \\
\text { Residence C, AD 1100-1522 }\end{array}$ & 0.11 & 0.01 & & & 0.11 \\
\hline GP.63 & Isla Alor, Huimanguillo, Tab. & 0.71 & 0.04 & 0.40 & 0.02 & 0.06 \\
\hline LP.64 & Totogal, Ver.,Totogal phase & 0.24 & 0.02 & 0.18 & 0.02 & 0.08 \\
\hline LP.65 & La Palma, Chis. & 0.26 & & & & \\
\hline LP.66 & Gonzalo Hernandez, Chis. & 0.10 & 0.02 & & & 0.17 \\
\hline LP.67 & $\begin{array}{l}\text { Tututepec, Oax., Yucu Dzaa } \\
\text { Residence B, AD 1400s }\end{array}$ & 0.16 & 0.02 & & & 0.10 \\
\hline LP.68 & $\begin{array}{l}\text { San Francisco de Arriba, Oax., } \\
\text { Operation 99J, Yucudzaa phase }\end{array}$ & & 0.02 & & & \\
\hline
\end{tabular}

Table 4. Coastal pressure blade percents through time.

\begin{tabular}{|c|c|c|c|}
\hline $\begin{array}{c}\text { Peri } \\
\text { od }\end{array}$ & $\begin{array}{c}\text { Assemblage Number or } \\
\text { Other Designation }\end{array}$ & Other Source; General Location & $\begin{array}{c}\text { Pressur } \\
\text { e Blade } \\
\text { Percent }\end{array}$ \\
\hline
\end{tabular}


Initial Formative 2000-1500 BC

\begin{tabular}{|c|l|l|}
\hline & Hirth et al. (2013) for San Lorenzo, & \\
\hline Ojochi, 1800-1600 BC & Ver. & 0.000 \\
\hline Bajio, 1600-1500 BC & as above & 0.000 \\
\hline IF.1 & Pacific coastal Chiapas & 0.000 \\
\hline IF.4 & Pacific coastal Chiapas & 0.000 \\
\hline IF-EF.5 & Pacific coastal Chiapas & 0.000 \\
\hline
\end{tabular}

Early Formative 1500-900 BC

\begin{tabular}{|c|l|r|}
\hline Chicharras, 1500-1400 BC & $\begin{array}{l}\text { Hirth et al. (2013) for San Lorenzo, } \\
\text { Ver. }\end{array}$ & 0.020 \\
\hline $\begin{array}{c}\text { San Lorenzo A, 1400-1200 } \\
\text { BC }\end{array}$ & as above & 0.060 \\
\hline San Lorenzo B, 1200-1000 & as above & 0.314 \\
\hline EF.6 & Pacific coastal Chiapas & 0.000 \\
\hline EF.9 & Pacific coastal Chiapas & 0.001 \\
\hline EF.11 & Pacific coastal Chiapas & 0.000 \\
\hline EF.12 & Pacific coastal Chiapas & 0.000 \\
\hline EF.13 & Pacific coastal Chiapas & 0.000 \\
\hline EF.15 & southern Gulf coast Tabasco & 0.200 \\
\hline & Hirth et al. (2013) for San Lorenzo, & \\
\hline Nacaste, 1000-800 & Ver. & 0.475 \\
\hline EF-MF.19 & near San Lorenzo, Veracruz & 0.478 \\
\hline
\end{tabular}

Middle Formative 900-500 BC

\begin{tabular}{|c|l|l|}
\hline MF.20 & Tuxtlas piedmont, Veracruz & 0.011 \\
\hline MF.21 \& MF.22 & Pacific coastal Chiapas & 0.005 \\
\hline
\end{tabular}

Late Formative 500-100 BC

\begin{tabular}{|c|l|r|}
\hline LF.24 & Pacific coastal Guatemala & 0.538 \\
\hline LF.25 & Pacific coastal Oaxaca & 0.068 \\
\hline LF. 28 & Pacific coastal Oaxaca & 0.341 \\
\hline LF.29 & south-central Veracruz & 0.031 \\
\hline LF.30 & Tuxtlas piedmont, Veracruz & 0.179 \\
\hline
\end{tabular}

Terminal Formative 100 BC-AD

300

\begin{tabular}{|c|l|l|}
\hline TF.32 & Tuxtlas piedmont, Veracruz & 0.417 \\
\hline TF.33 & Tuxtlas piedmont, Veracruz & 0.648 \\
\hline TF \& EC.34 & Pacific coastal Chiapas & 0.070 \\
\hline TF \& EC.35 & south-central Veracruz & 0.533 \\
\hline
\end{tabular}

Early Classic AD 300-600

\begin{tabular}{|c|l|l|}
\hline EC.36 & south-central Veracruz & 0.714 \\
\hline EC.37 & south-central Veracruz & 0.690 \\
\hline EC.38 \&39, LC.52 & south-central Veracruz & 0.878 \\
\hline EC.41 & south-central Veracruz & 0.780 \\
\hline
\end{tabular}




\begin{tabular}{|l|l|l|}
\hline EC.42 & Tuxtlas piedmont, Veracruz & 0.627 \\
\hline EC.43 & Tuxtlas piedmont, Veracruz & 0.750 \\
\hline EC.44 & Pacific coastal Oaxaca & 0.569 \\
\hline
\end{tabular}

Late Classic AD 600-900

\begin{tabular}{|c|l|r|}
\hline early LC.45 & Tuxtlas piedmont, Veracruz & 0.740 \\
\hline early LC.46 & Tuxtlas piedmont, Veracruz & 0.832 \\
\hline early LC.47 & Tuxtlas piedmont, Veracruz & 0.829 \\
\hline EC.40, LC.48 \&51 & south-central Veracruz & 0.899 \\
\hline LC.49 & south-central Veracruz & 0.725 \\
\hline LC.50 & south-central Veracruz & 0.804 \\
\hline LC.55 & south-central Veracruz & 0.324 \\
\hline
\end{tabular}

Early Postclassic AD 900-1200

\begin{tabular}{|c|l|l|}
\hline EP.56 & Pacific coastal Oaxaca & 0.744 \\
\hline EP.58 & Pacific coastal Oaxaca & 0.293 \\
\hline EP.59 & Tuxtlas Mountains, Ver. & 0.273 \\
\hline EP \& MP.60 & Pacific coastal Nayarit & 0.619 \\
\hline
\end{tabular}

Middle Postclassic AD 1200-1350

\begin{tabular}{|c|l|l|}
\hline MP.61 & Pacific coastal Oaxaca & 0.897 \\
\hline MP \& LP.62 & Pacific coastal Oaxaca & 0.986 \\
\hline
\end{tabular}

Late Postclassic AD 1350-1521

\begin{tabular}{|l|l|l|}
\hline LP.64 & Tuxtlas Mountains, Ver. & 0.627 \\
\hline LP.66 & Pacific coastal Chis. & 0.618 \\
\hline LP.67 & Pacific coastal Oaxaca & 0.879 \\
\hline LP.68 & Pacific coastal Oaxaca & 0.714 \\
\hline
\end{tabular}

General Postclassic AD 900-1521

GP.63 southern Gulf coast Tabasco

0.958

Note: Shaded cells have lower total obsidian count, 25 to $<50$.

Assemblages with less than 25 pieces of obsidian omitted.

Table 5. Comparison of median values for selected Classic and Postclassic assemblages

\begin{tabular}{|l|r|r|r|c|}
\hline & $\begin{array}{l}\text { Late } \\
\text { Classic } \\
\text { Median }\end{array}$ & $\begin{array}{l}\text { Postclassic } \\
\text { Median }\end{array}$ & $\begin{array}{l}\text { Difference of } \\
\text { Postclassic }\end{array}$ & $\begin{array}{l}\text { Percent change of } \\
\text { Postclassic Median }\end{array}$ \\
\hline Obsidian count/rim count & 0.416 & 0.162 & -0.254 & $61 \%$ less \\
\hline Obsidian count/sherd count & 0.032 & 0.018 & -0.014 & $44 \%$ less \\
\hline Rim count/sherd count & 0.059 & 0.1 & 0.041 & $69 \%$ more \\
\hline
\end{tabular}

Note: Late Classic assemblages 45, 46, 47, 49, 50, 51, 52, 54, 55

and Postclassic assemblages 58, 59, 60, 61, 62, 63, 64, 66, 67 